TURAI KATALIN RÁHEL

\title{
NŐK ÉS FÉRFIAK SZEXUÁLIS HÁRMASOKBAN
}

DOI: 10.18030/socio.hu.2015.1.162

\section{ABSZTRAKT}

Négy életútinterjú elemzésén keresztül járom körül, hogy milyen tapasztalatokat élhet meg valaki az egy nővel és egy férfival folytatott szexuális hármasokban, és ezek a tapasztalatok mit jeleznek a nemeknek a szexualitásban megmutatkozó társadalmi jelentéseiről. A vegyes hármas releváns viszonyulási pont a biszexualitással kapcsolatban, mert sokan ennek segítségével gondolják megérteni, mit jelenthet „egyszerre” vonzódni mindkét nemhez. Biszexuális vonzalmú (de nem feltétlen biszexuális identitású) nők és férfiak hármas narratíváinak elemzésével feltárom az élettörténetükben eltérően kibontakozó biszexualitásaik jellegzetességeit. A szexuális hármas eseményét így az egyén életútja során kialakuló meleg, biszexuális, vagy nem kategorizált identitásával, az adott szituáció társadalmi feltételeivel (pl. rendszerváltás, Pestre költözés, online társkeresők szerepe), valamint a szélesebb társadalmi diskurzusokkal (nők és férfiak barátsága, szexualitása) összefüggésben vizsgálom.

Az interjúelemzések rávilágítanak a queer elmélet nemi és szexuális kategorizációkat illető kritikájára: a biszexuális hármas tapasztalatát nem csak a két nem iránti vonzalmak; valamint ezen vonzalmakat sem csupán a női és férfi test biológiai különbségei határozzák meg. Van, akinek nemtől függetlenül a szexuális póz, másnak a szerelem és barátság érzése elsődleges. A hármasok pozitív élményében a résztvevők közti személyközi kapcsolatok is meghatározóak voltak, például a tartós szerelmi és alkalmi szexuális partner kombinációjában. A nemi különbség így társadalmi különbségeket jelenít meg; amelyek megélését van, aki „egyszerre” is igényli.

Kulcsszavak: szexuális hármas, biszexualitás, nemi különbségek, intimitás

\section{ABSTRACT - WOMEN AND MEN IN SEXUAL THREESOMES}

The experiences of sexual threesomes with a man and a woman, and thus the social meanings and significance of gender in sexuality are interrogated through narrative interview analysis. Such mixed-gender threesomes are relevant points in relation to bisexuality, because it promises comprehension of being attracted to both sexes at the same time. Through the analysis of threesome narratives of women and men with bisexual attractions (but not necessarily bisexual identities), I demonstrate the characteristics of their bisexualities, diversely unfolding in their life stories. I examine the experience of sexual threesomes thus in connection to the individual's gay, bisexual, or unlabelled identity shaped over the life course; to the social conditions of the situation (e.g. political changes, moving to Budapest, dating sites); and to broader social discourses (wo/men's friendships and sexuality).

My interview analyses illuminate the queer critique of gender and sexual categorizations: the experience 
of a bisexual threesome is not solely defined by the attractions towards both sexes; further, these attractions are not directed only to the biological differences of fe/male bodies. Irrespective of gender, sexual position and love and friendship can be primary. In the positive experiences of threesomes, the intersubjective relations, the combination of stable romantic and occasional sexual partners were decisive as well. Gender difference thus represents social differences - and some do need to experience those at the same time.

Keywords: threesome, bisexuality, gender differences, intimacy

„Keresünk egy pasit, aki jön hozzánk, és akkor mind a ketten jól érezzük magunkat vele [a női párommal]. Most jelenleg ez a helyzet. Mostmár egy másfél éve gyakorlatilag nekem nincs más kapcsolatom férfiakkal, tehát csak így a hármasozás kapcsán van az, hogy férfiakkal létesítek szexuális kapcsolatot. Úgyhogy. Hát, nem tudom, hogy mennyire meríti ez ki a biszexualitásnak a kategóriáját."(Márk, 34)¹

A szexuális hármasokkal kapcsolatos tapasztalatokat, és azok alapján a "férfi” és „nő" szexualitásban megmutatkozó társas jelentéseit járom körül négy interjú mélyelemzésén keresztül. A szexuális hármasok sokféleképpen folyhatnak le, a résztvevők nemétől, korától, a köztük levő kapcsolatoktól, a helyszíntől, esetleges ismétlődésétől, a kialakulás menetétől, a kommunikációtól, az aktusok tartalmától, irányától, és nem utolsósorban megélt jelentésétől függően. Ahogy Márk szavaiból is kiderül, a nemek szempontjából vegyes felállású hármas és a biszexualitás témája sokak számára együtt jár. A biszexualitással való összekapcsolódás és a férfi-nő összehasonlítás miatt a „vegyes” vagy „biszexuális hármasokat” tárgyalom, amely alatt olyan szexuális eseményt értek, ahol az interjúalanyon kívül van jelen egy nő meg egy férfi; amely időben behatárolt (tehát nem szerelmi háromszög jellegű kapcsolat, bár maga az aktus ismétlődhet), és amelybe mindhárom résztvevő fizikailag bevonódik. Mind a bevonódás, mind a „szexuális” mód meghatározásánál az interjúalany adott értelmezését követem, hiszen az elemzésem azokat a múlt- és jelenbeli jelentéseket próbálja meg rekonstruálni, amelyeket az illető rendel a hármas tapasztalatához.

\section{A QUEER ÉS A BISZEXUALITÁS SZOCIOLÓGIÁJA: ELMÉLETEK ÉS MÓDSZEREK}

Miért érdekes a szexuális hármasok témája szociológiai szempontból? 2010-ben, egy biszexualitásról szóló kutatás kezdetén meglepve tapasztaltam, hogy az interjúalanyaim közül milyen sokan szóba hozták a hármasozást. Anélkül, hogy rákérdeztem volna, kezdték el mesélni, hogy vágynak-e rá, el tudják-e képzelni, volt-e már ilyen élményük, és ha igen, hogyan élték meg. Ez egyértelműen jelzi, hogy a biszexualitással kapcsolatban a vegyes hármas szex olyan releváns viszonyulási pont (Garber 1996, 476), amelyen keresztül a résztvevők saját biszexualitásuk lehetőségére és jellegzetességeire rátekintenek, ahogy Márk is tette. ${ }^{2}$ A biszexualitásról szóló irodalom csak korlátozottan áll rendelkezésre, különösen magyarországi vagy közép-kelet-európai régiós vonat-

1 Az anonimitás érdekében az interjúalanyok maguknak választott álnevekkel és az interjúkészítés időpontjában adott koruknál pár évvel fiatalabbként vagy idősebbként szerepelnek a szövegben. Az interjúkban elhangzott összes tulajdonnevet vagy azonosítható konkrétumot is megváltoztattam. Dőlttel szedem a hangsúllyal kiemelt szavakat, zárójelben a nem verbális reakciókat; vastaggal pedig az elemzésben általam kiemelt kifejezéseket.

2 Éppen ezért a továbbiakban, akik nem tértek ki rá maguktól, azoknak is feltettem a kérdést az interjú végén, hogy mit gondolnak az ilyen hármasokról, azzal a céllal, hogy szélesebb körben összehasonlíthatóak legyenek az interjúalanyaim különböző vagy hasonló értékelései, és hogy azok milyen összefüggést mutatnak a biszexualitáshoz való viszonyukkal és szexuális élettörténetükkel. 
kozásban (fontos kivétel Borgos Anna magyarul 2010-ben megjelent cikke, amelyet két írásom követett, lásd: Turai 2010, 2011), de a szexuális hármasokról kulturális reprezentációik elemzésén (Garber 1996, 21. fejezet) túlmutató társadalomtudományi megközelítést szinte nem is találni. A nemzetközi populáris médiában való jelenlétén kívül - és gyakran arra reflektálva - jellemzően online médiumokban megjelenő, pszichologizáló vagy ismeretterjesztő jellegú írásokban kerül terítékre. Ezzel szemben az általam is követett szexuálszociológiai kiindulópont szerint a hármas ugyanúgy társadalmi tény, mint bármilyen kulturális gyakorlat (Laumann-Gagnon 1995, Tiefer 1995, Weston 1998, Kimmel 2007). Sem az aktus alakulása és megélése, sem az előzetes várakozások-motivációk, sem utólagos értékelése nem független az adott társadalmi kontextustól. A „tapasztalat” már eleve társadalmilag konstruált (Scott 1999), a vágyak és élvezetek az adott társadalmi viszonyokban, diskurzusokban és gyakorlatokban formálódva nyerik el jelentéseiket, ahogyan az egyén és a környezete interakcióiban értelmeződnek (Foucault 1999). Ezeket az értelmezéseket próbálom kinyerni az interjúrészletekből és összefüggésbe hozni az egyén életútjával, jelenlegi (és akkori) identitásával, az adott szituáció társadalmi feltételeivel és az általános társadalmi normákkal. Ennek segítségével tárom fel, hogy milyen szerepe van a társadalmi és biológiai nemi különbségeknek ezekben a történetekben; hogyan jelennek meg bennük a résztvevők, az interjúalanyt magát is beleértve, mint férfiak és nők.

Nemcsak a szexuális hármasok, hanem a biszexualitás is sokféleképpen „történik”, és rugalmasan definiálható. Azt az általánosan elfogadott meghatározást követtem interjúalanyaim kiválasztásakor, hogy saját bevallásuk szerint szexuálisan egyaránt vonzódnak-e férfiakhoz és nőkhöz. Ezeknek a vonzalmaknak a tükrében tapasztalatok, érzések, élettörténetek narratívákban kibomló színes skáláját kaptam: látni fogjuk, hogy a négy interjúalanyom is mind „másképp” biszexuális. A biszexualitás is történet: kitérőkkel, változásokkal tűzdelt elbeszélés, sokszor egy adott, stabil, változatlan identitás nélkül, és így jól példázza a szubjektum posztmodern, poszt-strukturalista megközelítését (Garber 1996 47, Hemmings 2002, 24-27). A szexualitás az interjúban is vallomásszerú narratív formában tárul fel, de nem mint egy meghatározott szexualitással eleve rendelkező személy útja, hanem mint ennek az „igazságnak” és ennek a személyiségnek a folyamatos előállítása (Scott 1993, Foucault 1999, Butler 2005, 2006). ${ }^{3}$ A biszexualitás csak időbeliségében érthető és mesélhető el - az egyetlen állókép, amely megragadni reméli, a vegyes hármas; sokan a hármasozás képének segítségével gondolják megérteni, mit jelenthet „egyszerre” vonzódni nőkhöz és férfiakhoz (Garber 1996, Hemmings 2002). A hármast ezért társadalmi szimbólumnak tekintem, egy olyan jól körülhatárolható képnek, amelyen keresztül nemcsak a biszexualitást és a szexualitás időbeliségét, hanem a nemek viszonyát is meg tudjuk közelíteni. Ebben a cikkben a biszexuális narratívát ütköztetem a biszexuális hármas képével.

Módszertani megközelítésem követi a queer elmélet célkitǔzését a szexuális és egyéb identitás-kategóriák dekonstrukciójában (Kalocsai-Takács 1998, Jagose 2003). Kutatásom kiindulópontja nem az identitás, hanem a vágyak sokfélesége egy emberen belül is, amelyek sokszor nem feleltethetőek meg a rendelkezésre álló kategóriáknak ${ }^{4}$ A nemi és szúkebben a homoszexuális identitások poszt-strukturalista kritikáját követve (Butler

3 Ez azt is jelenti, hogy interjúalanyaim narratív identitása az interjúkészítés pillanatára vonatkozik (ahogy a szövegben a velük kapcsolatban használt jelen idő is), amely az azóta szerzett tapasztalataik fényében változhatott, változott is.

4 Ezért tartom elhibázottnak Németh Barbara leszbikus narrativa-elemzésében (2008) a biszexualitás lehetőségének hiányát, ugyanakkor az „identitástagadás” mint analitikus kategória használatát egy olyan nővel kapcsolatban, aki heteroszexuálisként határozza meg magát, és nővel él párkapcsolatban. Ezzel ugyanis azt sugallja, hogy itt valójában leszbikusságról van szó, mintha az 
2005, 2006), a biszexualitás mint megkérdőjelezett identitás elemzése rámutat, hogy még a kevésbé átmenetinek tartott identitások esetében sem lehet rögzített kritériumrendszert felállítani, amely alapján minden embert be lehetne sorolni valamelyik kategóriába. Több interjúalanyom is van, akit bizonyos ismérvek alapján mind a homo-, a hetero- vagy a biszexuális kategóriába is besorolhatnánk, az interjúkészítés pillanatában adott narratív identitása és addig felhalmozott élettapasztalatai alapján. Márk például, akinek szavaival a tanulmány indul, hármasozik férfival-nővel; melegnek vallja magát; női élettársa van; nem vonzza a többi nő; kiábrándult a férfikapcsolatokból. Ezért tehát elsősorban melléknévi értelemben beszélek biszexuális élettörténetekről, vonzalmakról, vagy akár hármasokról, de főnévként, identitásként csak azokra alkalmazom a kifejezést, akik annak vallják magukat; és ugyanígy járok el a többi szexuális identitás-címkével is (lásd Young 1997). A queer értelemben nyitott biszexuális kategóriának a használata felvetheti a kérdést, hogy miért használom a biszexualitást mint praktikus leíró terminust, a queert pedig csak mint elméleti-elemzési fogalmat. ${ }^{5} \mathrm{~A}$ biszexualitás, még ha vitatott is mint jelenség, de köznyelvi szó, egyértelműen jelezve a férfiak és nők felé irányuló szexualitást, miközben a queer ismertsége a mai Magyarországon kicsi (bár növekvő), és csak a gender elméletekben vagy az $\mathrm{LMBTQ}^{6}$ aktivizmus bizonyos területein ismerős személyek tudnak róla. Juli (39) elbeszélése, ahogyan majd be is mutatom, sok szempontból queernek nevezhető, például amikor a szexuális identitáskategóriák értelmetlensége mellett érvel. Amikor azonban ezzel kapcsolatban rákérdeztem, kiderült, nem ismeri a queert és nem is érzi relevánsnak a saját kérdésfeltevései szempontjából - pedig ő diplomás belvárosi értelmiségi, meleg ismeretségi körrel.

A queer és a biszexuális elméletek ellentétének egyik sarokköve a nemek dichotómiája, amely a biszexualitás kifejezésben, sok kritikusa szerint, megerősítődik. A queer szemléletet valló biszexuális kutatók ugyanakkor arra hívják fel a figyelmet, hogy a queer által zászlóra tűzött bináris nemi és szexuális kategorizációk dekonstrukciójához elengedhetetlen a biszexualitás vizsgálata (Young 1997, Hemmings 2002: 10, Eisner 2013: 7). Kiindulópontom az, hogy a mai Magyarország társadalmában a nők és férfiak közti hatalmi egyenlőtlenség viszonyaiban konstruálódnak meg a nemi kategóriák, amelyek nagy jelentőséggel bírnak az interakciók minden szintjén, ezért használatuk indokolt akár olyan szociológiai elemzésben is, mint ez, ahol bizonyos aspektusaik lebontása megtörténik. Amellett fogok érvelni az interjúelemzés segítségével, hogy a férfi és nő által képviselt különbözőség egy szexuális hármasban sokszor egyéb társadalmi különbségeknek a megjelenítője, amely öszszefüggést elfedné, ha kizárólag a női-férfi testi különbségekkel magyaráznánk a szexuális élményt.

Két férfi és két nő számolt be személyes tapasztalatról biszexuális hármas tekintetében a 17 interjúalanyom közül.7 Ez is mutatja, hogy nem mindenki vesz részt hármasozásban, aki biszexuális vágyakkal ren-

identitás valami kétértékú és eleve létező dolog volna, pedig a kisszámú hivatkozott szexualitás-kutatás között említi a Replika queer különszámát (Kalocsai-Takács 1998).

5 Köszönöm az egyik anonim lektor javaslatát, hogy térjek ki erre a szempontra.

6 A Budapest Pride hivatalos nevében 2005 óta a biszexuális, 2012 óta a queer is szerepel, ebből a szempontból kezd láthatóságot kapni az utóbbi fogalom is. Ezért használom én is a mozgalomra az LMBTQ változatot, reprezentálva a leszbikus, meleg, biszexuális, transznemú és queer személyeket. Aki az interjúalanyaim közül queernek definiálta magát, azt jelen cikkben nem tárgyalom, mert nem vett részt hármasban (de el tudná képzelni). A négy idézett személy mindegyike egyértelmúen nőnek vagy férfinak sorolta be magát és partnereit is, ezért jelen tanulmányban eltekintek a (gender)queer vagy tág értelemben vett transz aspektusnak a tárgyalásától.

7 Az interjúalanyaimat ismerőseim révén találtam. 2010 és 2013 között, budapesti lakásukon vagy munkahelyükön, 1 és 2,5 óra közötti 
delkezik, sőt, nem is feltétlen vágyik rá. Pedig a vegyes hármas az „igazi” biszexualitás szimbólumaként jelenik meg a mainstream heteroszexuális és LMBTQ populáris diskurzusokban (Garber 1996, 21). A hármas szex így egy olyan, egyszerre látható és láthatatlan, egyszerre normatív és transzgresszív társadalmi fantázia (Wilkinson 2010), melyhez sokan viszonyulnak aktuális tapasztalat nélkül is. A négy tapasztalati narratíva összehasonlító elemzésén keresztül mutatom be, milyen jelentésekkel töltődhet meg a vegyes hármas a mai Budapesten.

A szexuális kategóriák definiálásának és megélésének folyamatait, az egyes szexuális események értelmezéseit, az identitás bizonytalanságait és többrétegúségét, az élettörténet diakrón kacskaringóit a kvalitativ módszerek tudják megragadni (Kovács-Vajda 2002: 25-27). De még a Queer Theory/Sociology címú kötetben közölt interjúalapú biszexuális kutatás (Ault 1996) sem teszi ezt meg maradéktalanul, mert nem integrálja az élettörténet keretébe a kategóriákkal kapcsolatos egyéni megfogalmazásokat. Seidman (1996) a kötet előszavában a queer szociológia szükségessége mellett érvel, amely a szexuális kategóriák jelentéseinek a (queer irodalomtudományi hagyományában hangsúlyos) fogalmi-kulturális elemzését ötvözi a strukturális és szimbolikus interakcionista társadalomtudományi megközelítésekkel - és ez az interjúalanyok szexuális értelemrögzítési folyamataira támaszkodó narratív kutatási módszert is leírja. Mivel én a hármasokban feltáruló értelmezett tapasztalatok társadalmi hátterét szeretném megérteni, kisszámú interjú elemzésére támaszkodom, a narratív-hermeneutikai elemzés kereteiben. Módszerem a narratív biográfiai megközelítés (Riessman 1993, Kovács-Vajda 2002, Kovács 2007) és a félig strukturált szociológiai-antropológiai elemzés (Denzin-Lincoln 2003, Gubrium-Holstein 2003) között helyezkedik el, az interjúk hosszának, számának, az interjúeri beavatkozásnak, valamint az elemzés mélységének megfelelően. ${ }^{8} \mathrm{~A}$ szexuális hármasok narrativáinak feltérképezésénél, ahogy a biszexualitások esetében is, elsődleges szempontom volt több egyéni életesemény elbeszélésének szociológiai összehasonlítása, hogy feltáruljon diverzitásuk a definiálás és megtapasztalás terén. Ugyanakkor pont ez a fluiditás követeli meg a felhasznált narrativák részletes elemzését, a közölt tartalmak reprodukcióján túlmutató jelentés-lehetőségek feltárását a megélés és az elbeszélés társadalmi kontextusában (Kovács 2007, 378); ami sok interjú esetében teljesíthetetlen egy cikk keretei között.

Ezeknek a szexuális hármas köré szerveződő tematikus narrativáknak mint szekvenciáknak a fókuszált, de nem szigorúan vett tematikus mezőelemzését végzem itt el, követve például Melegh (2006) módszerét, aki nem szexuális, hanem földrajzi-kulturális határátlépések narrativáit tárta föl. Felvázolom, milyen pontokon lehet szerepe a hármasnak mint életeseménynek a korábbi és későbbi életútban (kivételes/integrált/fordulópont stb.). Az interjús narratívák belső logikájának feltárása során azoknak a jelentéseknek a kibontására törekszem, amelyeket az alanyok adnak a maguk tapasztalatának. Hogyan alakult ki ez a hármas szexuális szituáció, milyen motivációk játszottak benne szerepet? Minek tulajdonítható, hogy pozitív vagy negatív tapasztalatként élték

időtartamban, hangrögzítéssel interjúvoltam meg őket. Az interjúrészletek idézésénél törekedtem a beszélt nyelvi jellegzetességek visszaadására, az érthetőség és folyamatos olvashatóság szempontjának figyelembe vételével (így a szóismétléseket, „teháthogy” jellegú töltelékszavakat kihagytam).

8 A biszexualitással kapcsolatban sokan bizonytalanok, mit és hogyan meséljenek; a szexualitás pedig eleve intim téma, amelyben nehéz megnyílni és megfelelő nyelvi regisztert találni. Volt, akit az segített, hogy egyáltalán nem ismertük egymást, más meg azért tudott megnyílni, mert ismert vagy én is meséltem magamról. A nők és férfiak iránti vonzalmak szempontjából elmesélt szexuális élettörténet első, megszakítatlan elbeszélése után az említett életeseményekre, majd néhány külső pontra kérdeztem rá. Minden esetben összevetettem a rekonstruált biográfiát az elbeszélói módokkal (azaz a megéltet az elbeszélt történettel), de nem haladtam végig egyesével a velük kapcsolatos hipotéziseken. 
meg az interjúalanyok? Hogyan kapcsolódik szexuális identitásukhoz és biszexuális vonzalmaikhoz a hármas, és mennyiben testesítette meg ezeket? Hogyan élték meg benne a nőkhöz és férfiakhoz való viszonyukat? Milyen jelentőséget tulajdonítanak a partnerek nemének, valamint a sajátjuknak? Milyen szerepet játszott az élményben addigi és későbbi kapcsolatuk más nőkkel-férfiakkal? Milyen hatások lelhetők fel a megélt és elbeszélt történetben az adott társas környezet és társadalomtörténeti kor különböző mintáinak tekintetében? Mire enged mindez következtetni a férfi és nő mint társadalmi kategória múködéséről a szexualitásban?

A négy interjúalanyom 34 és 45 év közötti, felsőfokú végzettséggel rendelkező személyek. Közülük két nőnek ambivalens vagy inkább negatív élmény volt a hármas, és két férfi nyilatkozott úgy, hogy egyfajta teljességérzést adott nekik. Míg Emese és Juli egy-egy alkalomról számolnak be, Márk és Szilárd ismétlődő hármasokról, azonos vagy eltérő felállásokban. Szilárd a húszas évei elején, a rendszerváltás utáni években tapasztalta meg a hármast; Emese, Juli és Márk a harmincas éveikben, nagyjából egyidőben, a 2000-es években. Mindegyiküknek volt már tapasztalata mindkét nemmel, de Emese számára a hármas egy kezdeti lépés volt a nőkkel való szexualitás kiteljesedésében. Bár a narratívák eltérnek egymástól a közölt szexuális-technikai részletek bemutatásában is, ${ }^{9}$ Emese történetében egyértelmü és hangsúlyos, hogy nem volt minden irányban érintkezés a résztvevő felek között. A következőkben sorra veszem a hármas elbeszéléseiket és megvizsgálom, azok hogyan helyezkednek el az élettörténetük és a társas közeg kontextusában, és milyen narratív identitások bomlanak ki belőlük.

\section{Nő A NŐVEL MINT FÉRFI A FÉRFIVAL}

Emese (37) magától tér rá a hármas élményére a másfél órás interjú első harmadában. A nagyjából kronologikusan, kulcseseményekből felépülő élettörténet a nők irányába is kitáguló vonzalmakról és azok megéléséről szól, homoszexuális coming out narratívák elemeit, fejlődéstörténeti ívét (Plummer 1995, 81-96, Seidman 1996) ötvözve a biszexuális identitásban való megerősödéssel. Az interjút azzal zárja, hogy egy tartós párkapcsolatra vágyik, akár nővel, akár férfival, mert „mindkettőnek megvan az előnye és a hátránya”. Kamaszkori barátnőjével, mielőtt kibontakozott volna, véget is ért a homoerotikus közeledés, majd a rendszerváltás és egy kisegyházban átélt erősen vallásos időszak után, vidéki városból Pestre költözve, harmincas éveire tudta megtapasztalni nőkkel a szexet egy politikailag is szabadabbnak megélt világban - ami elbeszélésében lépésrőllépésre történt. Emese sorra veszi ismerkedési kudarcait, nehézségeit és az együttlétek fokozatosságát szexuális szempontból: csók, mellsimogatás, a másik kielégítése és annak módjai, a maga kielégülése és annak módjai. Kétszer is kiemeli, hogy szerinte fontosak a szexuális részletek, „hogy mi alapján dönt valamelyik nem mellett”. A szexuális hármas, amely pár évvel az interjú előtt történt, szervesen illeszkedik a narratívának ebbe a szinte racionálisan mérlegelő - ugyanakkor a szexuális szenvedélyt előtérbe állító - keretébe, mint egy fontos lépcsőfok a nőkkel alakuló kapcsolataiban.

„És akkor az történt, hogy legközelebb, amikor összejöttem egy növel, az szintén egy ilyen nagyon nőies nö volt, és vele valahogy szintén neten ismerkedtünk össze, de vele tök sokszor találkoztunk, és így tulajdonképpen megszerettük egymást mint ember az embert. És éreztem, hogy ez azért jobb lesz. Tehát nem egy ilyen lelketlen valami. Nála meg az volt, hogy ott meg ő volt a félénkebb, mert ő nem volt abban

9 Nem kérdeztem rá külön, hogy részletezze, mi történt, hanem az interjúalanyra bíztam, hogy maga építse fel a történetet, olyan részletességgel, ahogy érzi az adott interjúhelyzetben; hiszen éppen ennek a konstrukciós munkának a megragadása volt a célom. 
biztos, hogy ő ezt csinálni fogja tudni, így kettesben, úgyhogy ö ragaszkodott ahhoz, hogy ez mindenképpen hármasban legyen, hogy legyen egy harmadik, egy férfi, aki az egészet így leirányítja. Egyébként ő huszonkettő éves volt, és talán azért is mondtam, hogy 'na jó, oké, hogyha neked ennyire kell az irányítás, akkor legyen'. És akkor hármasban! [felnevet] Aminek az volt a lényege, hogy én csak a lánnyal foglalkoztam, tehát szerencsére nem kellett a fickóval foglalkoznom. Hát ugye ez volt az ára, másképpen nem kaphattam meg a nöt. Na és az fenomenális élmény volt. Tényleg. De megint egyoldalú, mert én voltam az aktiv, és visszafele ez nem jött, mert ő meg ugye a fickót elégítette ki, tehát én a nöt, ő meg a férfit. Egyébként nem bántam, hogy így alakult, mert nekem ez így is csodálatos érzés volt, tehát ez, hogy én belehelyezkedtem a férfi szerepbe, és talán most azért is mondom, ezért érdemes egyébként belemenni a szexuális részletekbe, hogy tudd, hogy mi hajtja a nöket a nök felé. Eszméletlen jó érzés férfiként részt venni egy szexuális kapcsolatban."

Ez az együttlét fontos lépcsőfok volt, de, Emese szavaival, ugyanúgy nem „teljesértékü”, hanem „feles” élmény - az interjú során kiderül, hogy számára a kölcsönös kielégülés jelenti egy szexuális együttlétben a „beteljesedést", amiben később egy másik nővel volt része. Ebből az ismeretségből végül nem lett szeretet alapú párkapcsolat, ami szintén fontos számára, ahogy az idézet eleje mutatja - de Emese nagyra értékeli, amit szexuális szempontból ez a hármas élmény adott (lásd az elbeszélői jellegú történetmesélést kísérő „fenomenális”, "csodálatos”, „eszméletlen jó” értékelő jelzőket).

Felmerül tehát a kérdés, hogy akkor ez a hármas mennyiben volt pozitív tapasztalat Emese számára? Nem bánta meg, de nem is szeretné megismételni. Csak a nővel való élménye volt jó, a férfi jelenléte inkább zavarta. Tulajdonképpen Emese nem egy szexuális hármast, hanem egy szexuális párost mesél itt el, amiben a férfi mellékszereplő, akivel nem kellett foglalkoznia. Ugyan Emese „egyértelműen biszexnek” vallja magát, biszexuális vágyai ebben a szituációban egyáltalán nem kaptak szerepet. Az adott helyzetben nem volt igénye férfira, férfi-női hármasra sem - amit pedig, mint Márk nyitó mondata jelzi, sokan automatikusan összekapcsolnak a biszexualitással. A nővel akart ismerkedni, de az bizonytalansága miatt ragaszkodott egy férfi irányításához. Emese ezt a lány fiatal korának tudja be; valószínúleg az még fontosabb tényező, hogy mindketten a nőkkel való ismerkedés kezdetén voltak, heteroszexuális kapcsolatokkal a hátuk mögött, támogató-mintaadó leszbikus közösség nélkül. A leszbikus szexnek és eleve az önállóan vágyakozó és vágyaikat megvalósító nőknek ugyanis elég szúkös keretek között mozog a kulturális reprezentációja (Borgos 2014). A hármas ismerősebb terep volt a férfi (és így a heteroszexualitás) jelenléte miatt, és ez nyújtott a homoszexualitás felfedezésének egyfajta biztonságos keretet - vagy Gagnonnak, a szexualitás konstruktivista kutatójának kifejezésével, „forgatókönyvet” (script) (Laumann-Gagnon 1995, Kimmel 2007).

A 2000-es években a netes társkeresők magyarországi elterjedésével egyrészt elérhetőbbé váltak a homoszexualitás megélésének bizonyos formái, másrészt a műfaj jellegzetességei és a nemek eltérő szexuális szocializációja miatt ezek a nők számára sokszor hármas felállásban érhetők el a legkönnyebben. ${ }^{10} \mathrm{~A}$ biszexuális hármas nem mindegy, hogy két nőt-egy férfit, vagy két férfit-egy nőt takar. A két nő-egy férfi felállás jellemző-

$10 \mathrm{Az}$ internet elterjedése és a rendszerváltás előtt (mindkettő fordulópont volt a homoszexualitás megélésének lehetőségeit tekintve) baráti társaságok gruppenszex alkalmai adtak alkalmat nők közötti szexre (Borgos 2014). Sok férfi számára beteljesült fantázia barátnőjét egy másik nővel látni, anélkül, hogy az fenyegetné pozícióját és kapcsolatuk heteroszexualitását. Épp ezért sok leszbikus nő számára a hetero- vagy biszexuális nők ismerkedési szándéka komolytalan, és bizonytalansággal, veszteséggel fenyeget. 
en olyan hármas, amely heteroszexuális fantáziaként lehetőséget ad a nőknek a részvételre anélkül, hogy az megkérdőjelezné heteroszexualitásukat. Hiszen egymással való szexuális cselekményük nem annyira a saját homoszexuális vágyaik megéléseként, hanem a férfi partner (heteroszexuális) vágyának felerősítéseként értelmeződhet mindegyik fél számára. Sokszor a nők közötti szex így nem is számít „igazi” szexnek, viszont fokozza vonzerejüket. A nők szexuálisan elérhetőnek tűnnek, és a leszbikusság sokat hangoztatott „elfogadottsága” sokszor csak annyiban reális, amennyiben heteroszexuális férfiaknak szól vagy őket bevonja (Fahs 2009). Ellenben ha egy férfi csatlakozik egy heteroszexuális párhoz úgy, hogy a másik férfival is szexel, az homoszexuális vágyai egyértelmú bizonyítékának számít.

A női és férfi homoszexualitás társadalmi megítélésének különbségeit bőven tárgyaló szakirodalom Kinseytől (Kinsey et al. 1965: 475-485) a queer elméletig (Sedgwick 1985) levezeti, hogy a férfiak közötti fizikai intimitás azért esik szigorúbb kontroll alá, mert a férfiakat eleve fontosabb aktoroknak tekintik nyilvános társadalmi folyamatokban. Ez vezet a nők közötti szexualitás magánszférába rendeléséhez, valamint nyilvános jelenlétéhez annyiban, amennyiben az a férfiak számára szól vagy számukra hozzáférhető. A pornográfián kívül a két nő részvételével zajló hármasozás gyakorlata és annak popularizált képei is ide tartoznak. (Garber 1996: 424-479, Fahs 2009). A biszexuális hármasokban a nemek részvételének eltérő értelmezése a nők alárendelt társadalmi helyzetével áll összefüggésben - azonban végső soron bizonyos mozgásteret is ad a nőknek, akik ilyen formában megtapasztalhatják a homoszexualitást anélkül, hogy férfiak iránti vonzalmuk (férfiak számára való elérhetőségük) és nőiességük megkérdőjeleződne. De kilépniük a szexista-heteronormatív irányítás alól már jóval nehezebb. A férfiaknak a fizikai intimitás első lépéseit nehezebb megtenni, hiszen azok már a barátság keretein belül is heteronormatív tiltás alá esnek (lásd Albert 2014).

Emese, nőkkel való ismerkedése elején, „a sokadik kudarc” és kompromisszum után (például meggyőződése ellenére gyerekes és házas nővel is volt viszonya) a hármasba mint újabb kompromisszumba ment bele („ez volt az ára”), mert olyan elkeseredetten kereste a módot a nők iránti vágyai megélésére. Tulajdonképpen biszexualitása segítette hozzá homoszexualitása megéléséhez egy hármasban, mert így könnyebben el tudta fogadni ezt a felállást. Bár a hármas fontos lépcsőfok volt számára a teljes szexuális beteljesüléshez nőkkel, a biszexualitás számára nem lépcsőfok vagy átmeneti állapot a homoszexualitás felé, ahogyan azt (a biszexualitás létezését vagy legitimitását tagadó) bifób diskurzusok sugallják, kamaszos éretlenségnek vagy bizonytalanságnak tulajdonítva a biszexuális érdeklődést, vagy a ténylegesen létező homofóbiával való megküzdés szükségszerúen csak kezdeti lépésének (lásd Garber 1996: 305-347, Hemmings 2002: 25, Borgos 2010, Turai 2011). Emese nemcsak újra lép heteroszexuális kapcsolatokra, hanem évek óta vallja „biszex” identitását, amelyért heteroszexuálisok és leszbikusok bifób előítéleteivel is megküzdött.

Narratívája a résztvevők nemével szoros összefüggésben közelíti meg a hármasozás élményét, ahol a „fickó” egy lényegtelen vagy kissé zavaró mellékkörülmény, és a középpontban a „nőies nő” áll, akivel ő „aktív”, „férfi szerepben” szexel. Amit ez az élmény adott Emesének, az a másik nő kielégítésének „fenomenális” élménye. Itt azonban még nem ér véget az eset elbeszélése. Nézzük meg, hogyan folytatja onnan, hogy „Eszméletlen jó érzés férfiként részt venni egy szexuális kapcsolatban."

„Ezt egyébként korábban is megtapasztaltam, mert visszatérve a [már említett] meleg jóbarátomra, 
végülis kiderült, hogy annyira talán mégsem meleg, mert végülis lefeküdt velem. [nevet] És amikor ez megtörtént, és ráadásul háromszor, tehát ez nem volt véletlen [csettint], akkor én a fenekébe dugdostam a vibrátort, úgyhogy. Ja, és ezt ő annyira élvezte, hogy eszméletlen; úgyhogy akkor is megtapasztaltam, milyen így aktiv félnek, kvázi férfinek... tehát úgymond megdugni valakit. Hogyha csak egy vibrátorral is. De ebben a hármas szituációban kifejezetten, tehát egy ilyen felcsatolható vibrátorral csináltam, és az eszméletlen jó érzés volt. És [csettint] jó lett volna forditva is, és egyébként a lány is mondta, hogy szeretné majd megismételni, csak úgy, hogy ő legyen ebben a helyzetben. De aztán ez nem jött össze, mert ök nagyon ragaszkodtak ahhoz, hogy legközelebb megint hármasban legyünk, én meg baromira nem akartam hármasban lenni, kettesben meg nem akart velem lenni a lány."

Érdekes módon tehát a biszexuális hármasba mellékelbeszélésként beékelődik egy korábbi szexuális élmény, így vonva be a hármas megélt történetébe az elbeszéléssel egy negyedik felet: egy meleg férfit. Emese szexuális szerepe kapcsolja össze a két aktust, hiszen ott is „megtapasztalta[m], milyen így aktív félnek, kvázi férfinek... tehát úgymond megdugni valakit", és ott is a másik fél élvezete okozott neki örömöt. A köztük lévő viszonyt az aktív-passzív szerepben értelmezve Emese ott is magát érezte férfinak, a behatolás aktivitásától. Mindkét esetben vibrátorral tudott a partnerébe hatolni és őt kielégíteni, de a nővel folytatott szexben „kifejezetten, tehát egy ilyen felcsatolható vibrátorral" tette. Nem fejti ki ennek jelentőségét, de talán maga az a csípőmozgás volt nagy élmény, amely őt a pénisszel rendelkező férfiakhoz tette hasonlóvá. Sokkal nagyobb hangsúlyt helyez tehát ez az elbeszélés (és az itt is visszatérő „eszméletlen” értékelő jelző) Emese férfiasságára, mint a partner nemére. Ugyanaz okozott neki örömöt a meleg barátjával a szexben, mint a női partnerével: a másiknak élvezetet okozó behatolás. Végső soron így a szexben résztvevők nemének, sőt szexuális identitásának a jelentősége is megkérdőjeleződik, sőt, a párhuzamok hasonlóvá teszik a szexet két nő, egy férfi meg egy nő, és két férfi között. ${ }^{11}$ Emese megjegyzi, hogy a barátja „annyira talán mégsem meleg”, hiszen szexelt vele viszont ha úgy vesszük, hogy az aktus jellege Emesét férfivá tette, vagyis az ő biológiai nemének jelentőségét elhalványította, akkor akár tekinthetjük is a barátját melegnek, de az orientáció relevanciája is eltörpül a szex módja mellett. Ez mutatja egyrészt, hogyan konstruálódik meg a nem egy-egy cselekményben (Butler 2005, 2006), ahol a többi résztvevőhöz képest egy magát nőies nőnek érző nő tulajdonképpen férfivá válik. Másrészt Emese történetében queer módon megmutatkoznak a szexuális vágy és élvezet nemeken túlmutató elemei, amelyeket leegyszerűsítő redukció volna a hetero-, homo- és biszexualitás kategóriáival leírni. (Seidman 1996, Hemmings 2002, 113, Jagose 2003).

Ez a hármas tehát ennyiben kulcsélmény maradt Emese élettörténetében, de ahogyan elmeséli, az alapján ezután már nem akart több kompromisszumot kötni, szexuálisan sem, és kapcsolati szinten sem. Szerette volna a fordított felállást is kipróbálni, tehát nővel megélni a „passzív” szerepet, de férfival hármasban „baromira” nem. Egy másik nővel megtapasztalta a szexuális teljességet, de vallásos meggyőződésére hivatkozva, nem volt hajlandó belemenni a nyitott kapcsolatba, amibe a férj beleegyezett volna. Időközben egyre jobban beágyazódott az LMBTQ világba, csoportokba, programokra járt, talán emiatt is tudta az első homoszexuális tapasztalatok megszerzése után határozottabban meghúzni a számára fontos határokat, és egyben fenntartani biszexuális identitását.

11 Ezzel nem vitatom el annak jelentőségét, hogy Emese nőkre vágyott, csak rámutatok, hogy vágyainak milyen egyéb, a nemek testi jellemzőin túlmutató komponensei lehettek. 


\section{BARÁT(NŐ)I ÉS SZERELMI INTIMITÁS}

A másik női interjúalanyom a 39 éves Juli. Belvárosi értelmiségi, akinek egy-két férfival volt rövidebb és azóta több nővel komolyabb kapcsolata, amelyek alatt LMBTQ közösségek tagja is volt. Az interjú idején egy heteroszexuális párkeresés elején tart, egy olyan többéves önismereti folyamatban, amelyben „biszexuális” tapasztalatait próbálja megérteni: miért nem volt igazán jó se nőkkel, se férfiakkal, és miért érzi azt, hogy neki mégis férfiakra van szüksége, hogyan tudna hozzájuk közelebb kerülni.

Az egész interjú sokkal inkább argumentációkból, mintsem történetekből épül fel, reflexiók köré szerveződik; ez gyakori értelmiségi interjúalanyoknál, de Julinál ezt az aktuális én-újradefiniálás szükséglete is magyarázza. Nem kronologikusan vagy események köré szerveződik az elbeszélés, hanem a jelen gondolatait próbálja meg összerendezni, gyakori időbeli és tematikus (vissza-)ugrásokkal. Magát az interjút is úgy tekintem, mint Juli önismereti munkájának részét, egy újabb beszélgetést egy felületesen ismert emberrel, aki hasonló kérdéseket tesz föl, mint amelyek őt éppen foglalkoztatják - narratív identitása újrafogalmazása által így egy lépéssel megint közelebb kerül jelenbeli énkonstitúciójához (Tengelyi 1998: 23, Kovács-Vajda 2002:18, Diamond 2006). Önmagát, a nőkkel és férfiakkal való kapcsolataira adott érzelmi reakcióit elemezve próbálja megérteni, mi is az ő útja, hogyan és kivel múködhetne jól érzelmileg és szexuálisan. Ahogy az interjú legelején említi, ez egy új hozzáállás az önismeret folyamatában, nemcsak „megélni dolgokat és nyavalyogni”. A „megélést” itt az önértelmezéssel állítja szembe, utalva arra, hogy korábban csak reflektálatlanul megtörténtek vele dolgok, és ezeket most utólag meg kell értenie. Ezért az egész élettörténetet a múltbeli „megtörténéssel” szemben magasabbra értékelt jelenbeli emlékezés-értelmezés strukturálja.

A hármas történet az interjú utolsó harmadában került elő, én tettem fel a kérdést, hogy mit gondol róla. Szinte semmi konkrétum nem derül ki az elbeszéléséből, nincs is történet, csak öt mondat szól röviden egy esetről, utána pedig a sok argumentáció és értékelés; egyrészt úgy tűnik, nem tudja/akarja az élményt felidézni, ugyanakkor narrációs szempontból nem lóg ki az életút egészéből. Egy hosszabb, laza szövésű, nem egyértelmúen lehatárolható tematikus szekvenciában mesél a hármasról, ugyanis amikor én már azt hittem, lezárta a témát, újra meg újra visszakanyarodik hozzá.

„Szerintem, nekem ugyanúgy nem oké. De egyszer kipróbáltam... [kis nevetés] És ugyanazt gondolom, hogy nem oké, nem tudom, miért mentem bele, hülye voltam, és nagyon... terelgethetö. És akkor volt egy barátnőm, meg a pasija, és nagyon jóban voltunk, én meg egy szakitás után voltam, és így jólesett a törödésük. És akkor egy kicsit [kis nevetéssel] ők ezt továbbgondolták. Azóta is egyébként jóban vagyunk, tehát nem tört össze a dolog, csak szerintem nekem ez nem oké. Tehát nekem a szex az pusztán szexröl nem tud szólni. Vagy nem, nincs hozzá kedvem, hogy csak pusztán szexről szóljon. Most is így gondolom, lehet, hogy ez is változhat, de az intimitás meg nem fér bele [a hármasba] nekem. Tehát ök egy pár voltak, utána egy darabig még egy pár is maradtak. És azóta most pont a Gábor mesélt egy ilyenröl, nem ő volt benne, hanem az egyik barátja, meg a barátnője, meg még egy lány. És így az is tök szarul alakult. De van, akinek persze ez jól alakul, csak mondom, nekem ez így. (...) Nekem a szexualitás, inkább szeretkezésnek a szépsége az két embernek a nagyon közelisége. Tehát mint ahogy egy társas beszélgetés más, mint egy kettes beszélgetés, ugyanúgy, ha ketten beszélgetek valakivel, és a szerelmem, vagy a nem tudom, a párom, vagy nem tudom, hogy hívják még ezt ilyen terminológiával, de hogy az az 
ember, akit nagyon szeretek, és azzal még közelebb vagyok, nemcsak átölelem, hanem még ez az össze... olvadás, ez szerintem. Az az én ideális eset-gondolatomban az két emberről szól. És az most mindegy, hogy két milyen típusú ember, mármint milyen nemü ember, de két ember. [11 mp szünet] Az összes... Tehát a hármasozás az nekem ilyen kísérletezés inkább, meg ilyen határfeszegetés abban az értelemben, amilyen értelemben mondjuk, megintcsak azt mondom, az én fejemben, a drogozás határfeszegetés. Tehát nekem az olyan, hogy én így kipróbáltam. Mittudomén, tán füvet? már így nagyon-nagyon régen. És így az se hiányzott úgy különösebben. De azt hiszem, hogy így mást nem is. De nem vágyom arra az élményre, hogy ezt most kipróbáljam. Tehát azt hiszem, hogy egy csomó olyan élményt, aztán így lassan 40 évesen föleg azt gondolom, hogy megkaptam vagy megkapok, és még lehet, hogy fogok is, nem tudom, amit így nem is gondoltam volna. És akkor ha anélkül is meg lehet, akkor meg minek? ezt így mechanikus úton eröltetni, vagy vegyi anyagokat tenni a szervezetedbe?"

Ezek után, mivel úgy túnt nekem, hogy lezárta ezt a szakaszt, a biszexualitás kategóriájáról kérdezem. Számára az semmi kapaszkodót nem nyújtó fogalom, majd miután hasonlóan érvel a queer kapcsán (lásd a bevezetőt), így folytatja:

„Szerencsére nem voltam olyan helyzetbe sokszor, hogy kellett volna magamat kategorizálni. Azt hiszem, hogyha most kéne, tehát hogyha van egy olyan tapasztalásom, hogy vannak dolgok, amik jók, és utána is jók. Tehát mondjuk megéled jónak, vagy érdekesnek, vagy izg[isnek], vagy nem tudom, és aztán szívesen visszaemlékszel. És vannak olyan dolgok, amik izgisek, de aztán vissza, rájössz, hogy így nem jöttél ki jól ki belöle. Tehát fáj a lelked, vagy itt [szívére mutat] érzed, hogy nem, nincs helyén. Na, és hogyha, például ilyen érzésem volt, hogy nem tettem jót magamnak, a hármasozással például. Vagy mondjuk ha például valaki berúgik, mint az idióta, és aztán utána másnap rosszul van. Tehát kábé ez az az ér[zés], amiről beszélek, hogy így lehet, hogy akkor egy csomó mindent kihoz az alkohol, ami el van feszülten nyomva, vagy nem tudom, de hogy ezt nem biztos, hogy azzal kellett volna, mert aztán másnap meg széthányja a belét. Tehát hogyha abból indulunk ki, hogy mi az, ami... mi az a szexuális élmény, ami után nem volt itt ilyen probléma, az tök nehéz, mert ugye a nöknél mindig volt utána, hogy nem vagyok a helyemen, a pasiknál meg nem volt jó maga az élmény, tehát hogy nem volt igazán jó szexuális élményem. (...) És akkor most mi, aszexuális vagyok? Énszerintem inkább az van, hogy nekem ez egy nagyon kevéssé felderített meg kevéssé kipróbált terület, és hogy ezzel még egy csomót kéne dolgoznom. És remélem, hogy ha minden jól megy, akkor még tudok vele tapasztalásokat gyüjteni."

Ebben a részletben is kiemelkedik a megélés/tapasztalás és az emlékezet diszkrepanciája: a történéseket újraértelmezi a történések után közvetlenül, és később a baráti beszélgetésekben, illetve magában az interjúban is. Juli narratívája egyértelműen bizonyítja, hogy önmagában véve, ezek nélkül a folyamatosan változó értelmezések nélkül nem létezik szexuális tapasztalat, még az egyéni élvezet szintjén sem (Laumann-Gagnon 1995). Érdekes módon a szexuális kategorizáció az a láncszem, aminek kapcsán visszakanyarodik a hármashoz, mint aminek az értelmezéséhez szintén nem nyújtanak neki segítséget a mainstream kategóriák, csak a saját folyamatban lévő, aktív önelemző munkája (amivel zárul is az idézet).

Az egész szekvenciát a vége felól, a problematikus szexuális élmények perspektivájából tudjuk megérteni: onnan olvasva a legelső mondatban kissé homályos referenciájú „ugyanúgy”az összes többi szexuális élményre vonatkozik, amelyek vagy közben, vagy utána nem voltak jók. És ez számára szervesen összefügg azzal, hogy „szerencsére nem voltam olyan helyzetbe sokszor, hogy kellett volna magamat kategorizálni”, hiszen a 
standard szexuális identitáskategóriák helyett fejlesztette ki a maga számára az egyes szexuális tapasztalatok utólagos értékelését mint módszert az önismeretre és stratégiát a későbbi cselekvésekre. Ahogy a „párt” a szerelemmel, szeretettel határozza meg, Juli számára a szex is inkább „szeretkezés” (azaz érzelemmel telített), amely két ember összeolvadásáról szól. Ezt kettes aktusokban se tudta megélni, a vegyes hármas elbeszélése tehát narratíve nem különül el az élettörténeti narratívában; egy (utólagosan) negatív élmény a többi közt. A biszexuális felállásnak sincs számára specifikuma, ki sem tér a férfi-női jelenlét különbségeire. Annak ellenére, hogy az élettörténete a nők és férfiak iránti eltérő viszonya köré szerveződik, a szexuális részleteknek nem tulajdonít nagy jelentőséget, maximum a saját szexuális vágyának, de inkább a lelki-agyi folyamatok érdeklik; a kettő hierarchikus oppozícióját többször is a fejére/szívére és a nemi szervére mutatva fejezte ki.

A hármasozást a drogozáshoz, később az alkoholizáláshoz hasonlítja, amelyben határfeszegetéssel, „mechanikus úton erőltetve" juthatunk olyan élményekhez, amelyek vagy nem hiányoznak, vagy más úton, spontán is megtapasztalhatók. A szexuális élmények utáni kellemetlen érzést a másnaposság drasztikus hasonlatával („széthányja a belét”) tudja megragadni, jelezve, hogy itt valamilyen frusztrációnak a valódi megoldását kikerülő pótcselekvésről van szó. Az „erőltetés”, „terelgetés” képe is az autentikusság nyelvezetéhez kapcsolódik, amely központi kérdés a szexualitással kapcsolatban általában is, de a biszexualitással és a hármassal kapcsolatban mindig felmerül, hogy „valódi” vágyakról van-e szó, vagy pedig valamilyen megfelelési kényszerről (Hemmings 2002, 43, Fahs 2009). Juli utólag úgy értékeli, hogy valójában talán nem is vágyott arra, ami ténylegesen létrejött; mintha valamilyen erőszakosság és az ő részéről gyengeség is jelen lett volna. ${ }^{12}$ Akár önhibáztatásnak, szégyenérzetnek, az utólagos undornak is tulajdonítható, hogy nem mesélte el a hármast mint „sztorit”, ellentétben Emese színes, részletes történetével. Az ő narratívája rámutat, hogy még egy olyan, a populáris kultúrában sokszor könnyednek, tétnélkülinek mutatott témában is, mint a szexuális hármasozás, akár az aktuálisan átélt fizikai/lelki élvezet mellett is, fájdalmas momentumok, korábbi sebek tárulhatnak fel. Ennek ellenére, legalábbis az eset akkori megélésében, mégiscsak volt valamilyen pozitív, érzelmi alap, hiszen jó barátai vigasztalták egy szerelmi csalódás után („jólesett a törődésük”). Nem egyértelmű, hogy a baráti szeretetet megtapasztalta-e az együttlétben, csak hiányolta a szerelmet, vagy pedig úgy élte meg, mintha érzelmi kiszolgáltatottságát használta volna ki a pár a maga élvezetére. Hangsúlyozza a baráti kapcsolatuknak (és a másik két fél párkapcsolatának) fennmaradását, de a „nem tört össze a dolog” kifejezés azt mutatja, hogy egyértelmúen kellemetlen élmény volt számára. Ezt nem is tartja meglepőnek, hiszen ismerősei is hasonlóan tapasztalták meg a hármast - tehát a saját hármas narratívájába beleúszik a mások tapasztalatáról akár közvetve szerzett tudás, amely megerősíti a saját értelmezését.

A barátság kérdése azért is érdekes, mert Juli a nőkkel való kapcsolatairól is úgy számol be, hogy azok általában barátiból csúsztak át szerelmi viszonyba - ahogy láttuk, a nők közötti barátságban ez könnyebben meg tud történni a fizikai (és lelki) intimitás elfogadottsága miatt (Sedgwick 1985, Albert 2014). Az intimitás nagyon fontos fogalom számára, erre törekszik, ezt várja a szexuális együttléttől: a két ember összeolvadásának képét nagyon hangsúlyossá teszi az utána következő (élő beszédben rendkívül hosszú) 11 másodperces szünet, még

12 Kutatások szerint a biszexuális nők szenvedik el a legtöbb párkapcsolati erőszakot heteroszexuális és leszbikus társaikhoz viszonyítva, ami részben annak tulajdonítható, hogy már pusztán a vonzalmaik miatt is szexuálisan kihasználhatónak túnnek a férfiak számára (Fahs 2009). 
ha nem is tudhatjuk, min gondolkodott el. Jelzi, hogy ez az intimitás két nő között is létrejöhet, viszont a hármasban nem - amire a szünet után visszatér, aláhúzva benne a spontaneitás hiányát. A biszexuális hármasban tehát számára sem a résztvevők neme, mint inkább az számít, hogy túl sok a szereplő benne, és így nem tudja megadni, amit ő keres, a szexuálisan is kielégítő páros intimitást.

Férfiakkal intimitást eddig nem tudott megélni, a barátnőivel igen, ugyanakkor nem érezte igazán jól magát ezekben a kapcsolatokban, „nem voltam a helyemen”, ezért szeretne most férfiak felé nyitni, és bízik benne, hogy talál egy olyan férfit, aki más, mint a többi. Ebben megerősítette, hogy néhány férfival nemrég mély barátságba is került. A baráti és szerelmi-szexuális intimitás határai tehát eleve összefolynak Juli életében: nők esetében szeretné ezeket különválasztani, férfiak esetében pedig ötvözni. Valószínúleg ebben a hármas élményben is azzal kellett szembesülnie, hogy neki elsősorban baráti közelségre volt igénye, amely a két másik résztvevő kezdeményezésére/nyomására vált szexuálissá. Úgy értelmezem ezt a kissé töredezett narratívát, hogy ebben a hármasban is az zavarja a jelenből visszatekintve, ami az eddigi női kapcsolataiban: hogy nem húzta meg a szexben a szerelem-barátság határvonalat, és az önképében negatív elem, hogy ebben befolyásolható volt, hiszen ő a „szeretkezés” élményét keresi. A hármas kapcsán mindenkinél megjelenik az érzelmi alapú intimitás és a "csak szex" kérdése, és ahogy látni fogjuk, a hármas pozitív tapasztalataiban is fontos elem lesz a résztvevők közti érzelmi viszonyulás mértéke az otthonosság-idegenség tengelyen. Juli számára az az ideális, ha a szex csak szerelmi kapcsolatban jelenik meg, és így barátság és szerelem is világosan elkülöníthető. Korábban, barátnőinél (ahogy maga a szó is kettős értelmú), ez a szétválasztás nem történt meg.

Juli jelenlegi célkitúzése a korábbi nemi kategorizációinak felülírásán alapszik, azon a meggyőződésen, hogy férfitól is meg tudja kapni azt a fokú intimitást, amit korábban csak nőkkel tudott megélni: „nem kéne ezt így skatulyázni, hogy vannak a pasik meg a nők. Hanem van egy csomó idióta nö, és kedves nö, és van idióta pasi és kedves pasi." Saját erőfeszítéseinek nagyobb jelentőséget tulajdonít a férfiak felé való nyitás lehetőségében, mint azoknak a társadalmi normáknak, amelyek a női-férfi intimitás eltérését eredményezik; ha ebben az individualizáló-pszichologizáló megközelítésben nem is, de a szexuális kategóriák megkérdőjelezésében a queer elmélet gondolatmenetét követi. Az identitáskategóriák értelmetlensége, sőt, érdektelensége mellett érvel, mert azok egyszerűen nem írják le az ő tapasztalatait - és itt nemcsak a homo- és hetero- (és bi)szexualitás egységéről van szó, hanem a „szexualitásról” mint valakinek az általános jellemzőjéről. Ezért teszi fel a tematikus szekvencia végén a kérdést mint a külvilág lehetséges, de ugyancsak értelmetlen, mert számára megválaszolhatatlan kérdését: „akkor most mi, aszexuális vagyok?”, amelyre a válasza tulajdonképpen újra az önismereti munka. A saját érzéseire próbál figyelni, hogy milyen volt a női és férfi ismerőseivel a kapcsolata, akár baráti, akár szexuális. Úgy érzi, ő nem tartozik bele sem a leszbikus, sem a heteró kategóriába. Juli narratívája a queer kritikákban megfogalmazott (szexuális és egyéb) identitáspolitikák represszív múködésmódját is jelzi: az identitáscímkében rejlő közösségformáló és mobilizáló erő egyben a kategorizáció kényszereként múködik, és az identitás meghatározott formájú vállalását, bizonyos hozzátartozó elemek felmutatását követeli meg (Seidman 1996, Kalocsai-Takács 1998, Jagose 2003, Butler 2006, Borgos 2010).

Nemcsak arról van szó, hogy a vonzalmai alapján kilóg ezekből a csoportokból, hanem gyakorlatilag kulturálisan is. Ugyanis társadalmi helyzete, életstílusa, valamint baráti, politikai kötődései alapján (egyetemi vég- 
zettség, belvárosi lakás, civil és nemzetközi szférában végzett munka, kulturális programok, liberális-baloldali beállítódás, LMBTQ barátok és csoportok) szinte elvárásnak élte meg, hogy magára öltse a leszbikus vagy meleg identitást és életstílust, amellyel mégsem tudott azonosulni. Ő tehát egyfajta belső kritikáját adja ennek a rétegnek és az általuk képviselt elveknek (nem csak szexuális téren, pl. a neoliberalizmusnak is). Frusztrációját fejezi ki a magyar társadalom kulturális-politikai megosztottsága miatt, amelyet ő a szexualitással kapcsolatban is megtapasztal mint kétfelől érkező nyomást a „döntésre” (ahogy ezt még az identitásukban teljesen biztos biszexuálisok is megélik, Isd. Ault 1996, Borgos 2010). Aláhúzza, milyen sokat kapott konzervatív-jobboldali barátoktól, akik nem akarták befolyásolni, csak mellette álltak és meghallgatták.

Bár Emese élvezettel és tapasztalatokkal gazdagodva, Juli pedig mint kellemetlen eseményt élte meg a hármast, mindkettőjük történetében megjelent a nőkre rótt kényszer, melyet akkor, ugyan különböző okok miatt (baráti vigaszt vagy leszbikus szexélményt keresve), de elfogadtak. Ma már talán egyikük sem tenné (vagy ha igen, nem ilyen okokból), mert mindketten felismerték és meghúzták a határaikat a vágyaik-igényeik körül. Juli határozottabban leválasztja a szexuális érdeklődést a barát(nő)i viszonyairól, és küzd azért, hogy szexuálpolitikai „terelgetések” helyett az egyéni szexuális-kapcsolati igényeinek legmegfelelőbb utat megtalálja.

\section{AZ EGY NŐ ÉS A SOK FÉRFI ${ }^{13}$}

A nyitó idézetből megismert Márk (34) első, negyed órás élettörténeti narratívájának lezárásaként mesélt nem gyakori, de rendszeres, és az interjú jelenében is fennálló hármas élményeiről mint kulcsmomentumról mind a múlt, mind a jelen szempontjából. Ezek nemcsak kronologikus végpontját, hanem szinte csúcsát is jelentik „szexuális pályafutásának”, és egyfajta sürítését adják biszexualitásának, illetve annak, amennyire, amilyen értelemben őt biszexuálisnak lehet nevezni. Ezért kérdeztem rá ezután a hármas elbeszélés után az önmeghatározására, amelyben a férfiakhoz, illetve Hannához, a párhoz való viszonyáról gondolkodva végül arra jut, hogy „ha mondjuk nézünk egy ilyen, nem tudom, egy ilyen Kinsey-skálát, ami nem tudom, hogy hány fokozatú, már nem emlékszem rá (...), inkább azt mondanám, hogy azért inkább, tehát közelebb vagyok így a homoszexualitáshoz, de nem mondom azt, hogy abszolút az vagyok". Korábban csak férfipartnerei voltak, és más nőhöz most sem vonzódik. Nyitott kapcsolatban élnek, amelybe beleférnek hármas együttlétek is. Nézzük meg a korábban idézett interjúrészletet a hozzá kapcsolódó értékelések, a lehetséges reakciók kontextusában.

„Tehát egyrészt úgy is pasizhatok, hogy csak kettesben egy pasival, de szoktunk úgy is partnert keresni, hogy hármasban. Tehát keresünk egy pasit, aki jön hozzánk, és akkor mind a ketten jól érezzük magunkat vele. Most jelenleg ez a helyzet. Mostmár egy másfél éve gyakorlatilag nekem nincs más kapcsolatom férfiakkal, tehát csak igy a hármasozás kapcsán van az, hogy férfiakkal létesítek szexuális kapcsolatot. Úgyhogy. Hát, nem tudom, hogy mennyire meríti ez ki a biszexualitásnak a kategóriáját. Hát nagyjából ennyi a kis szexuális pályafutásom."

Önmeghatározásról, biszexualitásról, féltékenységről mesél ezután, majd ezek kapcsán újra visszakanyarodik a szexuális hármasok témájához.

13 A fejezetcímet Radnóti Sándor Az Egy és a Sok címú tanulmánya (2007) ihlette, amelyben hasonlóan központi elem a Párhuzamos történetekben ábrázolt élmények, testek és személyiségek egymásra íródása, a páros és többszörös szexuális kapcsolódások relációja, a szexuális és nemi határok átjárása. 
„Tehát [ha hármasban], akkor nem kell utána erröl különösebb [kis nevetés] referendumot tartani, hogy akkor ez hogy történik, meg mint. Úgyhogy. És hát pasizni meg ugyanúgy tudok. Tehát végülis... Meg hát olyan szempontból végülis azt kell hogy mondjam, hogy izgalmasabb is. Ez a fajta [köhint] játék, hogy több tényezös a dolog. Tehát hogy akkor ott a Hanna, aki szintén izgalmas, meg ö a szexben azért ismert. Tehát hogy ismerem a testét, ismert az illata, tehát otthonos is ily módon ez az együttlét, meg ott van benne mindig egy újdonság is. Vagy hát nem mindig, mert azért vannak visszatérö kuncsaftjaink, de [nevet] de van benne azért újdonság is, hogy akkor jön egy új ember, meg új illatok, meg új kuki. Szóval azért jó, izgalmas, izgalmasabb ez így szerintem."

Ez a biszexuális hármas az interjú jelenében is fennálló, rendszeres esemény, amely lehetővé teszi valamilyen („többtényezős”) kettősségnek a pozitív megélését, ahogy az első idézet tudósító hangvételét követő részlet jelzőkben gazdag értékelése egyértelművé teszi. Ebben a narrativaában hangsúlyosan férfiakról és nőkről van szó, pontosabban több névtelen férfiról, és egy néven nevezett nőről, Hannáról, akivel közös projekt a férfipartner („kuncsaft”) keresése és bevonása, akivel valószínúleg részben közösen kidolgozott a narratívájuk. Elsősorban az ismerős-ismeretlen, stabil-új dichotómiát emeli ki („ismert, otthonos, új, újdonság”), és ennek a többszörösségnek (nem csak az új partnernek) az izgalmasságát. Garber $(1996,419)$ azt írja, hogy a „biszexuális házasságok" nem a biszexualitás paradoxonját jelenítik meg, hanem általában a kibékíthetetlen ellentétet a házasság stabilitása és a szexuális vágyak zabolázhatatlansága között, amelyre megoldást jelenthet a nyitott kapcsolat, ahogy Márk esetében maga a vegyes hármas is. Számára fontos, hogy így a férfiak iránti vonzalmait is meg tudja élni (mint „inkább meleg”).

Ennek ellenére a női és férfi test különbözőségét nem hangsúlyozza. Az „új kuki” jelzi a férfiak biológiaitesti jelenlétének fontosságát, de amitól izgalmasnak tartja, az nem annyira a Hannának, hanem a korábbi férfiaknak a testétől, nemi szervétől való különbözősége, ahhoz képest jelentkező újdonsága. A „férfit” a sokaság, a változatosság definiálja, a „nőt” az egyetlensége, Márk szexualitásában szó szerint kivételessége (valamint stabilitása); tehát elsősorban mint két eltérő, egymás relációjában létezőkapcsolati forma jelennek itt meg (lásd: Radnóti 2007). Márk hozzájuk való viszonyulása, az érzelmek, az együtt kialakított élet, a találkozás gyakorisága különbözteti meg őket egymástól. Hanna (35), akivel szintén készítettem interjút, röviden említi ezeket a hármas együttléteket: ő ugyanúgy az ismerős-idegen dichotómiában tapasztalja meg és igényli ezeket az együttléteket Márkkal és egy másik férfival, amelyek számára így nem is biszexuális hármasok. ${ }^{14}$ Kettejük értelmezési kerete tehát nem tér el annak ellenére, hogy azonos vagy különnemú partnerekkel kerülnek relációba. Az új és otthonos kettőssége megfeleltethető a Juli narrativájában (valamint általában a biszexuális diskurzusokban, lásd: Turai 2010) jelentős szerelem és szex dualitásnak, ugyanakkor Márk életében és értelmezésében a szerelmi kapcsolat nem jelent szexuális kizárólagosságot. Sőt, számára a „csak szex” kapcsolat is érték, még ha csak önmagáért való játék is. Valószínúleg éppen a biztonságos, otthonos közegben zajló kaland lehetősége az, amit számára a hármasok nyújtanak. ${ }^{15}$

Csak két barátjuk tud ezekről a kalandokról, tehát maga az interjú is egy vallomásos narratíva. A többi ismerőssel kapcsolatban mondja a következőket (és egyben le is zárja a témát):

14 Bár korábban volt kapcsolata nőkkel, női partnerre és vegyes hármasra már nem vágyik. 
„Nem hiszem, hogy ezek az emberek, hogyha megtudnák azt, hogy vannak ilyen kalandjaink, az nagyon befolyásolná a kapcsolatunkat velük. Nyilván ha befolyásolná, az akkor az elsősorban róluk szólna olyan szempontból, hogy ő ezzel a témával nem tud mit kezdeni. De hát ezzel meg mi nem tudunk mit kezdeni. Meg hát igazából tényleg senkinek semmi köze a mi szexuális életünkhöz, hogy azt hogyan meg mint éljük. De talán abból, ahogy egyébként megéljük az életünket, abból meg azért feltehetöleg lehet arra következtetni, hogy ezt a dolgot is józan ésszel meg felelösséggel csináljuk. Tudod, van aki buliba jár, meg van aki narkózik, meg van aki alkoholizál, mi meg, nekünk meg ez a káros szenvedélyünk, bár eddig nem bizonyult károsnak [nevetünk]. Kérdés az egyébként, ilyen lelki szempontból, tehát felmerül az a kérdés, hogy ez lehet, hogy káros-e. A mi kapcsolatunk szempontjából. Mondom, eddig ennek jelét nem láttuk. Majd kiderül, valamikor egyszer biztos."

Érdekes, hogy Julihoz hasonlóan ő is a droghoz és alkoholhoz hasonlítja ezeket az élményeket, a szexet a függőségek közé soroló diskurzusokhoz kapcsolódva. Míg azonban Juli párhuzama negatív értékelést adott a hármasnak a saját belső normáihoz viszonyítva, Márk narratívája a feltételezett külső reakciók fényében egyrészt normalizálja, mint sok szokás közül egyet, másrészt azokkal szembeállítva magasabbra is értékeli, hiszen „nem bizonyult károsnak”. A „szenvedélyt” kiegyensúlyozza a „józan ész és felelősség”, amivel ők ezen és életük más területein is mozognak, ami megintcsak a hármasok és általában a szex hétköznapiságát, normalitását, polgári keretek közé illeszthetőségét húzza alá. Márk öniróniával jegyzi meg, hogy tisztes konzervatív vallásos család benyomását keltik; stabil egzisztenciális körülmények között, vidéki kertes házban élnek, az LMBTQ életben is már alig vesznek részt. Ezek az együttlétek az ő titkuk, ami a közösen létrehozott otthon falai közt történik, és senki nem gondolná róluk. Kitapintható Márknál is a Juli interjújában hangsúlyos magyar politikai-kulturális megosztottság, amely összeegyeztethetetlennek tételezi a konzervativizmust (vallásban, pártpolitikában) a nem-normatív szexualitással; talán ezért is tartozik az ő történetmeséléséhez is hosszabb evaluáció és argumentáció arról, hogy miért jó számukra a hármas és miért lehetne elfogadható a külvilág számára is, ha kiderülne. Ugyanakkor azzal, hogy titkolják, mégiscsak a közeg normáit követik. Márknak így lehetősége van homoszexuális vágyai megélésére azok nyilvános felvállalása nélkül (a korábbi, részben nyílt meleg életével szemben). ${ }^{16}$ Számára egységben van ez a titok a nyilvánosan látható életükkel; narratívája saját maga és a külvilág elképzelt reakciójának irányába is teljes mértékig integrálja a biszexuális hármasokat az önképébe és élettörténetébe. Ez az ő jelene, korábbi életpályájának bizonyos értelemben a célpontja, egy olyan állapot, amelyben megtalálta az összhangot különböző igényei között, az adott társadalmi közeg mozgásterében.

Mivel ezekről a hármasokról röviden Hanna is mesélt nekem, az ő perspektívája is megvilágítja Márk tapasztalatát, és a hármasaikban résztvevő férfiak (Márk és a többiek) biszexualitásának kérdését. Hanna számára a monogámia parancsának megszegése szempontjából érdekes ez a téma, nem pedig Márk szexuális orientációjának szempontjából. Sőt, azzal zárja a hármasról szóló szekvenciát: „Szóval nekünk aztán igazán vannak biszexuális ismerőseink!" - értvén ezalatt alkalmi partnereiket, tehát ő sem gondolja, hogy Márk biszexuális lenne, vagy őhozzájuk hasonlóan lenne biszexuális. Ugyanakkor Márk interjújának egy későbbi pontján feltárult a résztvevő harmadik férfiak perspektívája is, legalábbis Márk értelmezésében. Amikor rákérdeztem, hogy ismer-e olyan embert, akit biszexuálisnak nevezne, újra a vegyes hármassal kapcsolatos tapasztalatait hozta szóba, ezúttal férfi partnereik szemszögéből. A hármas szexen belüli újabb határhúzással demonstrálta, hogy ő kit tart „tényleg biszexnek”. 
„És volt nálunk olyan pasi, aki [köhint] úgy volt vele, hogy mondjuk az meg volt engedve, hogy én simogassam. Tehát a Hannával igazából mindent. Tehát ilyen szempontból a férfi-nő közötti kapcsolat[ban] szerintem minden belefért neki. Tehát dugás, nyalás, csókolózás, gyakorlatilag bármi. A férfiak között viszont a csókolózás az nem fér bele, az orális szex az belefér. Tehát az, hogy szopatok és szopok, az mind a két oldalról belefér, és igazából ennél több nem nagyon. Illetve még ami érdekes, hogy mondjuk az anális szex az érdekli öket, és érdekes módon a passziv oldalról, tehát hogy öket dugjuk, dugják meg. De mondom, tehát én inkább azt gondolom, hogy ők ezt az érzést keresik, tehát. Az is elhangzott egy-egy ilyen faszinak a szájából, hogy van neki kis kütyüje, tehát gondolom egy müfarok, amivel ö szokta magát izgatni, vagy ilyesmi, és nyilván ugyanezt az érzést akarja egy ilyen hármasban is megélni. De nyilván az a kütyü, tehát az megintcsak egy ilyen személytelen meg lélektelen kütyü. Tehát azt gondolom én, hogy valahogy ezt az érzést keresik. És maga a férfitest egyébként meg úgy nem... tehát az olyan felesleg, nagyjából. Tehát voltak ilyen pasis kalandjaink is. De volt [köhint] egy-kettő olyan, amire azt mondom, hogy ez a pasi ez tényleg biszex, mert... tehát ugyanolyan módon viselkedett velem is a szexben, mint a Hannával. És akkor azt mondom, hogy ez a Kinsey-skálának valóban a közepe, mert akkor minden irányban meg van engedve, illetve van vágy, a különböző játékoknak az irányába, tehát hogy csókolózzunk, simogassuk egymást, orális szex, oda-vissza, tehát ez megvan."

A hármasban szexelés módja szintén sokrétű, és újabb meg újabb határvonásokra nyújt lehetőséget a résztvevők értelmezésében. Márk szerint azok a férfiak biszexuálisok valóban, akik minden típusú aktusban részt vesznek mindkét partnerrel, az úgynevezett aktív és passzív relációkban is. És itt a csókolózás volt számukra döntő, mert előfordult, hogy csak abban mutatkozott meg a különbségtétel, azaz hogy az illető férfi Márkkal nem csókolózott. Azért is érdekes ez, mert a csók, épp a köznapisága miatt, sokak számára enyhébb foka a szexuális érdeklődés kifejeződésének, ahogy több női interjúalanyom csókot még el tudna képzelni nőkkel, de annál „komolyabbat” nem. Ugyanakkor Márk értelmezésében (a férfiak szerint) a csók a személyes viszony, és így a másik férfi mint test és lélek iránti érdeklődés jele, míg az orális és anális érzeteket jobban el lehet távolítani a személytől, és szinte egy „kütyüvel” is helyettesíteni lehet (a csók jelentéseinek változatos társadalmi konstrukcióiról lásd: Tiefer 1995). Érdekes, hogy ami Márknak „személytelen meg lélektelen kütyü”, egy dildó vagy vibrátor, az Emese mindkét történetében pozitív elem volt, ami lehetővé tette számára (felcsatolva még inkább) a „férfi szerep” élvezetes megélését, és így a másik félhez való kapcsolódást. Ő talán hasonló „érzést keresett", mint azok a Márk szerint nem-igazán-biszexuális férfiak, akiknek az anális behatolás testi érzete volt az elsődleges, és nem a partner nemi teste.

Ugyan Márk megkülönbözteti a nem egészen és egészen biszexuálisokat, de nem azért, hogy saját „igazi” biszexualitását bizonyítsa, ahogyan hasonló kizárások a marginalizált csoportidentitások erősítő eszközei szoktak lenni (Ault 1996, Butler 2006). Sőt, ő az interjúban már korábban feltárta, hogy mennyiben nem biszexuális. Szerinte ezek a „tényleg biszex” férfiak a skálának valóban „a közepén” vannak, vele ellentétben. ${ }^{17}$ Azonban a csókot mint kategorizációs eszközt magára nem vonatkoztatja; ő nem úgy nem egészen biszexuális, mint a férfiakkal nem csókolózó férfiak; hanem úgy, ahogyan elmesélte. Legalább háromfajta biszexualitás tárult tehát itt föl, csak a hármasozásban résztvevőkön belül. Márk hármas élményei nem lennének értelmezhetők az élettörténete nélkül, amely megvilágítja többek között a különbséget közte és a többi nem-egészen biszexuális férfi között.

17 Márpedig Kinseynek (Kinsey et al. 1965, 1999) éppen az a megállapítása forradalmi, hogy a szexuális vonzalmak és élmények skálaszerűen szóródnak a kizárólagos homo- és heteroszexualitás pólusai között. 


\section{SZERETET ÉS SZERELEM SZÖVEDÉKEI}

Az átlagosnál hosszabb, szinte megszakítatlan élettörténeti elbeszélés harmadánál került elő a szexuális hármas mint többször, ugyanabban a felállásban megismétlődő élmény Szilárd (45) életében. Szerves része a kronologikusan építkező élettörténetnek, amely a nők és férfiak iránti (eltérő) vonzalmai alapján strukturálódik. Emeséhez hasonlóan Szilárd is coming out narratívákat mozgósít fejlődéstörténeti keretben, amely az önmegvalósítást a homoszexuális vágyak elfogadásával és realizálásával kapcsolja össze, és nála egyértelmúen a meleg vagy szinte-meleg identitás perspektivájából szerveződik az élettörténet-konstrukció (Plummer 1995). A rendszerváltás „zűrzavaros” éveiben, húszas évei elején költözött (Cseh)Szlovákiából Magyarországra, első meleg kapcsolatait társkereső lapok segítségével szerezve. Néhány évig egy baráti közösségben, összetartó „kommunában” élt, amely támogató hátországot jelentett a még részben otthon lakó nagykamasz tagoknak is, amilyen a történetben szereplő Gyuri és Lili. Az interjú korábbi pontján mesélt Gyuriról, akibe szerelmes volt, de Gyuri „heteró”: tulajdonképpen baráti alapon „engedte neki, hogy leszopja”, ebben merült ki köztük a szexuális kapcsolat. Szilárd sokszor explicite fogalmaz, de meg-megtorpan: az alábbi részletben is kétszer reflektál a nyelvi megformálásra. ${ }^{18}$

„Hozzátartozik, hogy akkoriban mi, a Gyurival, hogy mondjam ezt szépen. Tehát mi dugtunk a Lilivel [mosolyogva] rendszeresen, ketten a Gyurival. Tehát a Gyuri akkor volt olyan tizenhat-öt, én voltam huszonegy-kettö, a Lili meg volt tizenhét. [8 mp szünet, kis nevetéssel folytatja] Tehát ez egy érdekes dolog volt. Nagyon, nagyon jó visszaemlékezni rá egyébként. Szerettük egymást, és jó volt együtt, volt benne egy kis naivság is, ilyen rácsodálkozás az egészre. Tehát amikor pornófilmet látok, meg ilyen bizonyos filmeket, ilyen swingerpartyk, meg ilyen össze-vissza izé, tehát ez nem ilyen volt. Ez teli volt érzelemmel. Tehát mi szerettük egymást. És mindenki, tehát nem voltak titkaink, mindenki tudta, hogy a másik kit szeret, érted? A Lili tudta, hogy én imádom a Gyurit. Ez egyébként úgy volt, hogy mi dugtunk a Lilivel, teljesen véletlenül egyszer ott aludt, mert vidéki volt egyébként, csak nem tudott hazamenni idöben, és akkor ott aludt, és akkor valahogy nem volt máshol hely, és [lassabban] együtt feküdtünk az ágyba, de nem úgy, ilyen nagy elökészülettel, hanem valami farmer is volt rajtunk, szóval valami ilyen komolytalan izé. És akkor, ahogy ilyen simizésböl összejött ez a dolog, és akkor én gondoltam, hogy tök jó. És akkor úgy maradtunk, hogy egy hét múlva megint jött - egy idő után azért láttam rajta, hogy nagyon rámkattant, Úristen, nem kéne, hogy elbízza magát azért, én nem, soha nem hitegetek senkit semmivel. Mert én tudom, hogy az ásó-kapát nem tudjuk megcsinálni, akkor meg minek hinni ezt. És akkor a Gyuri egyszer siránkozott nekem, hogy milyen jó nekem, mert én a Lilivel, izé. És akkor halál komolyan, mondtam neki, hogy 'te figyelj, [nevetve] hát majd meglátom, mit tehetek! Megdumálom vele!' És esküszöm neked, megdumáltam Lilivel. Megbeszéltük. Egy kóla vagy egy hot-dog mellett így megbeszéltük, hogy 'te figyelj, olyan aranyos ez a Gyuri, hát. Hát, nem volt még növel. [halkan] Kisgyerek, nem volt még növel, csak messziröl nézegeti a nőket, hát. Mi lenne, ha.' Végülis azt nem tudom, mennyire tetszett ez az ötlet Lilinek, hogy ôt ez felcsigázta-e, vagy. Tehát hogy mondjam. Tehát a Gyuri csigázta fel-e - most nem tudom, hova kell az e betüt a magyar nyelv szabályai szerint -, tehát hogy a Gyuri miatt vállalta be, vagy pedig, mert gondolhatott arra is, hogy ez engem annyira felhúz vagy feldob, hogy nekem akart ezzel jót tenni, ezt nem tudom. Mindenesetre, én teljesen kész voltam. Tehát én megláttam őket, együtt, akkor én már ott helybe elmentem [nevet]. Az egy érdekes időszak volt, akkor. Bár el tudnék képzelni most is olyat, 
bizonyos emberekkel vagy emberrel meg tudnám tenni. De akkor, ötször-hatszor egy éjszaka alatt képes voltam elélvezni. Szóval az a Kánaán volt. Egyik oldalamon egy fiú, másik oldalamon egy lány [nevetünk]. És mindketten szeretnek engem, vagyok annyira önzö, disznó szemét állat, hogy nekem ez fontos."

Ahogy a „Kánaán” szó is jelzi, Szilárd számára ez a hármas egy ideális állapot volt, szinte paradicsomi, utópisztikusan irreális élethelyzet. Ártatlanságukhoz („naivság és rácsodálkozás”) és a köztük lévő szeretethez köti szexuális szabadságukat. Akár egykori aranykornak, elveszett paradicsomnak is értelmezhetjük, hiszen - a többiektől eltérően - számára a fiatalkori ártatlanság majd’ húsz éves története. A jelenben már csak egy szép emlék: „nagyon, nagyon jó rá visszaemlékezni” (talán amikor szünetet tart, akkor is emlékeibe réved). Szilárd esetében a megélés és az emlékezés-elbeszélés egyaránt pozitív, ellentétben Juli narrativájával, de ő is tükrözteti a múltat és a jelent: az idézet végén elgondolkodik, mennyiben történhetne meg ugyanez most.

A hármasozás számukra állapot volt, nem csak egyszeri alkalom, még ha kísérletező játéknak is indult, hanem meglévő szeretetkapcsolatok rendszeres kifejeződése. Lilit és Gyurit Szilárd néven nevezi - egyedül az ő interjújában ismerjük az összes szereplő nevét, ezzel kiemeli a hármasuk érzelmességét és személyességét, és személyközi kapcsolataik egyenrangúságát (ellentétben Márkkal, aki számára élesen elkülönült az állandó partner egy Hanna a változó férfiaktól). Ezzel, valamint nyílt kommunikációjuk párbeszédszerű visszaadásával mintha cáfolni szeretné azt az előítéletet, hogy a hármas ne lehetne érzelmi alapú, egyenlő és őszinte, amelyek a poliamorikus kapcsolatok jellemzői (lásd Easton-Hardy 2009 klasszikusát). Ugyanakkor elhatárolja magát a pornótól meg a swingerezőktől, reagálva a nem-páros szexnek ezekre a médiában egyeduralkodó sztereotipikus képeire (Wilkinson 2010) mint érzelemmentes és nem hiteles ábrázolásokra.

Hogy ilyen egyértelmúen pozitív emlék Szilárd számára ez a hármas, azt a szereteten kívül a két nem jelenlétével is magyarázza, „egyik oldalamon egy fiú, másik oldalamon egy lány”. A történet talán biszexuális vágyainak igazolásaként is szolgál, hiszen az interjú során sokszor kifejezi, hogy úgy érzi, többet kéne nőkről beszélnie. ${ }^{19}$ Ő az egyetlen, aki az interjúalanyaim közül ekkora hangsúlyt helyez a női és férfi jelenlétre. Ezzel megidézi azt a heteronormatív elképzelést, hogy a két nem alapvetően különbözik, ezért komplementer módon kiegészítik egymást (Butler 2006: 46). A biszexuális hármas egyrészt megerősíti ezt a képet, ugyanakkor meg is bontja annak logikáját, hiszen a vágy ebben a diszkurzív rendszerben a tőlünk különbözőre irányulna, és a hasonló (azonos nemú) társ csupán az azonosulás, identifikáció tárgya volna (Garber 1996: 363), Szilárd és Márk márpedig mindkét irányban vágyakozott.

Tovább bonyolítja a hármas múködésének megértését a kérdés, amit Szilárd felvet Lili motivációjával kapcsolatban: hogy a részvételt és az élvezetet milyen többszörös vágyak tudják motiválni. Nem olyan egyszerú a képlet, hogy mindenki vágyik a másik kettőre, hanem az is meghatározza a vágyakat, hogy a harmadik személy mit szól a többiek ketteséhez. Az egyének összekapcsolódása egy hármasban nem csak a testi érintkezésben valósul meg, hanem a látványban is, az azonosulások és vágyak többirányú, akár feszültségterhes megtapasztalásában (Dollimore 1996). Lili érzelmi pozíciója kérdéses számomra ebben a történetben, hiszen kiderül a részletből, hogy Szilárdhoz jobban kezdett kötődni, mint ő hozzá. Kettejük szexuális együttléte mint kronológiai előzmény ékelődik bele a hármas történetébe, és kontrasztban áll azzal a spontaneitás és az érzelmi 
kiegyenlítetlenség tekintetében (ami valószínúleg fennállt a hármasban is, de Szilárd ott a kölcsönös szeretetet élte meg és elbeszélésében azt hangsúlyozza). Tehát akár Lili kiszolgáltatottsága is belejátszhatott abba, hogy beleegyezett a hármasba, hogy így közvetve kielégítse Szilárd vágyát akár a maga, akár Gyuri irányába („nekem akart ezzel jót tenni" - fogalmaz Szilárd), azaz ebben a felállásban is megbújhat a nők szexuális kihasználása, egy hasonló kompromisszum, mint amibe Emese ment bele. Még az is lehet, hogy Szilárd erőteljes értékelése a saját szeretetigényéről („vagyok annyira önző, disznó szemét állat”) utal arra, hogy bármennyire is kiegyenlítettként meséli el a háromszöget, érzékeli a benne rejlő egyenlőtlenséget. Szilárd Lilin keresztül, vele azonosulva is részesült a szerelemmel szeretett Gyuriból olyan szinten, ahogy vele kettesben nem tudott (hiszen kettejük szexuális élete a viszonzatlan orális szexre korlátozódott). Természetesen a szeretet is motiválhatta őket abban, hogy Gyurinak a nővel való szex élményét megadják, ami talán még jobban összekovácsolta őket. Az ő hármasuk esetében tehát a baráti, szerelmi és szexuális kötődések egymással is kölcsönhatásban vannak, és - Juli tapasztalatától eltérően, aki ezeket szeretné különválasztani - mindegyik belejátszik abba, hogy Szilárd számára annyira pozitív volt az élmény.

Gyuri figurája egy másmilyen biszexualitást is megmutat, hasonlóan ahhoz, ahogy Márk határolta el magát a férfi partnereiktől. Gyuri, persze Szilárd értelmezésében, heteró, aki a kamaszkori nyitottságban, a barátság keretei között még nem bánja az egyoldalú szexuális kapcsolatot: „a puncira vágyik, az ő élete láthatóan afelé fog folytatódni, hogy majd ő családos lesz, gyereke lesz, izé. De van egy olyan korszaka, amikor megengedi neked, hogy... 'Hát figyelj, jó barátom vagy, miért is ne'". Szilárd azonban már nagyon korán elhatározta, hogy nem fogja ezt a heteronormatív életpálya-modellt követni („tudom, hogy az ásó-kapát nem fogjuk megcsinálni”). Gyuri heteroszexuális „,beavatásával” így tulajdonképpen elősegítette kettejük kapcsolatának lezárulását is, de tisztában van annak ideiglenességével. Kettejük együttlétének látványa az, ami neki a legnagyobb gyönyört okozta, amit orgazmusainak gyorsaságával és magas számával szemléltet (ennél többet nem is tudunk meg a szexuális részletekről). Ezzel azt is kifejezi, hogy szexuális teljesítőképesség tekintetében is ebben az „érdekes időszakban” volt a csúcson. Bár jó ideje csak férfiakkal van kapcsolata, Szilárd számára ez az időszak nem egy átmeneti, már lezárult biszexualitás fázisa volt, ahogyan azt az univerzalizáló, bifób kamasz-biszexualitás toposza sugallja (Garber 1996: 347). Ahogy majd kitérek rá, később is volt női kapcsolata, amelyet párhuzamba is állít ezzel a hármassal. Ugyanakkor, ahogy Szilárd, úgy az elemző számára is felmerül a kérdés, hogy mennyiben lenne megismételhető ez az élmény a jelenben, azaz mik voltak a társadalmi lehetőségfeltételei a múltban.

Azokban az években Szilárd a szabadságot élte meg különböző területeken, és ez mutatkozott meg ebben a hármasban is, „bármit bevállaltam akkoriban”. Már a történetet is úgy vezeti fel, hogy „most jön egy érdekes sztori”, és magát az interjút is „kalandos utazásnak” nevezi. Számára az utazás, a szexualitáson keresztül, szó szerint is értendő, hiszen határon túli magyarként került Budapestre, ahol meleg ismerősei segítségével kezdett teljesen új életet, mint ami a szlovák vidéken várta volna. Melegségének megélése a városi élettől és a rendszerváltás jelentette „felszabadulástól” elválaszthatatlan, úgy, mint Emesénél láttuk (Weston 1998). Szövegében megjelenik az új életmód tárgyi környezete, farmer, kóla, hot-dog, ami az akkori, családi kötöttségek közül kiszabaduló fiatalt lenyűgözhette. „A rendszerváltás környékén itt egy nagy zürzavar volt” - mondja Szilárd. Az átalakulóban lévő társadalmi viszonyoknak, a szabad piac szabályozatlanságának és a civil csoportosulások szabadságának együttesen köszönhető, hogy akkor ez a laza szerveződésú „kommuna” létrejött és múködőképes 
volt, vállalkozásokkal, nagyratörő tervekkel. Sok tekintetben alternatív életforma volt, a vegetarianizmustól a nem-monogám, homoszexuális szerelemig; a nem-hagyományos kapcsolati háló egyfajta alternatív családként funkcionált (Weston 1998), de Szilárd tudta, hogy csak ideiglenesen áll fenn.

Ez a „kommuna” érdekszövetségként segítette tagjait - a hármas együttlét narratív előzménye, hogy Szilárd nagyon szerette volna megkapni a magyar állampolgárságot, és arra gondoltak, hogy a Lilivel kötött házasság elő fogja ezt segíteni. A Lilivel leírt szex spontán, természetes módon történt, „tök jó” élmény volt Szilárdnak, de a kettejük kapcsolatába belejátszottak Szilárd aspirációi mind az állampolgárság, mind Gyuri felé - Gyuritól pedig az ő szerelme nem kapott viszonzást, de az egyenlőtlenségek ellenére a baráti szeretet minden irányban fennállt köztük. Szilárd számára az egész életútban a nők járhatóbb utat jelentenek, egyrészt szexuálisan elérhetőbbek, mint sok férfi (pl. Gyuri), másrészt a velük kialakított kapcsolat társadalmi előnyökkel jár (állampolgárság, később az idősebb nő jelentette egzisztenciális biztonság). Ugyanakkor legidősebbként ő támogatta Gyurit, szexuális tapasztaláshoz is segítve, tehát terelgetni, irányítani tudta mindkettejüket.

Érdemes megnézni Szilárd életének későbbi fejezeteit, ahol szintén felbukkannak párhuzamos kapcsolatok. Például a jóval idősebb férfipárja mellett fiatal fiúk („Sok évig éltünk együtt, közben volt egy-két fiú, vele még ezt is meg lehetett beszélni"), vagy amikor egyszerre volt viszonya egy fiatal fiúval és annak anyjával (akik egy ideig nem tudtak egymásról). Az anyával kapcsolatban mondja Szilárd, „Jó volt. Szeretett. És ez olyan érzés volt nekem, mikor a jobbomon Gyuri, és a balomon Lili." A fiatalkori biszexuális hármashoz hasonlítja ezt az időszakot, noha itt hármas együttlétről nem volt szó, csak párhuzamos kapcsolatokról. Szintén adott egy nő meg egy férfi, de két korosztályt képviselnek, és a nem és kor kombinációjának megfelelően két eltérő kapcsolatformát. Az idősebb nő a stabilitást, (anyagi, szabadidős, társadalmi) biztonságot, szeretetteljes légkört, a fiatalabb fiú a baráti viszonyt, szórakozást, alkalmi szexuális együttléteket, átmenetiséget - amit csak bonyolít, hogy egymással szülő-gyermek kapcsolatban állnak, így Szilárd mintha mindig a másikat is képviselné, amikor az egyikkel van. Ehhez pedig teljesen hasonló a két férfival folytatott viszony, ahol a nemi különbség helyét, mondhatni, teljesen átveszi a kor. Szilárd tehát igényelte és az összes párhuzamos kapcsolatában meg is élte a különbözőségek komplementer teljességét (a saját szerepeiben is), amely különbözőségekben a nem csak egy volt a sok közül. Szexuális és párkapcsolati választásait tehát nem kizárólagosan biszexuális vonzalmai határozták meg.

\section{ÖSSZEGZÉS: NŐRE ÉS FÉRFIRA VÁGYNI}

Ezen a négy narratíván keresztül megismertünk négyféle történetet arról, miképpen történik meg valakivel egy (vagy több) hármas szexuális élmény. Spontán baráti beszélgetésből, előre megtervezetten, szerelmi kapcsolatban, idegennel, jóbaráttal. Van, akinek rendszeres, múködő tapasztalat, és van, akinek a kihasználtság kellemetlen élménye volt. Azonban nem pusztán az volt a célom, hogy a hármas élmény sokféleségére rámutassak, hanem hogy a tematikus elbeszéléseket társadalmi keretbe helyezzem, az életutakban és (változó) identitásokban játszott szerepét kibontsam. Hiszen a hármas történeteken keresztül megismertünk négy embert is, meleget, biszexuálist, inkább homoszexuálist és az identitáscímkéket elutasítót, akik különféleképpen, életutuk során is eltérően vágynak női vagy férfi partnerekre. Az elemzés megmutatta, a biszexuális hármas értelmezése nagyban függ attól, hogy a résztvevők akkor és a jelen elbeszélésében milyen szexuális igényekkel 
és identitásokkal rendelkeznek, és azokat hogyan tudják összehangolni különböző társadalmi normákkal, amik a partnerek és (valós vagy elképzelt) kívülállók hozzáállásában is tükröződnek.

Amikor a vegyes hármas a biszexualitás szimbóluma, akkor egy állóképben megragadható definíciót ígér egy sokak számára nehezen felfogható jelenséggel kapcsolatban. A biszexualitást akár mint identitást, akár mint vonzalmat megkérdőjelező bifób diskurzusok kétségbe vonják, hogy valaki ténylegesen vonzódna mindkét nemhez, tudna valóban szerelmes lenni mindkettőbe, szexelni velük, ugyanannyira-e, ugyanannyiszor-e stb. (lásd: Turai 2011). Az általam nők és férfiak iránti vonzalomként definiált biszexualitás, ahogyan megjelenik az emberek tapasztalataiban, szinte soha nem tud megfelelni ezeknek az elvárásoknak, hiszen ezerféleképpen alakul a vonzalmak-gyakorlatok-érzelmek-kapcsolatok időben is változó kombinációiban. A felvázolt négy élettörténet is négy eltérő szexuális életút és szubjektumképződés narratív folyamata, amelynek csak egyik eleme az identitáskategóriákkal való azonosulás vagy azok elutasítása, igazolva ezzel a queer elmélet kritikáját az identitáspolitikákkal szemben (Kalocsai-Takács 1998, Jagose 2003).

A biszexuális hármas ismert jelenség, jelentősége van annak, ki mit hall róla - a diskurzusok így jelennek meg a személyes narratívákban, az élményhez való viszonyban. Ezért láttuk azt, hogy nem is voltak egyértelmúek a hármasok narratív határai: egymásba ágyazódtak mások hármas élményeivel (mint Juli ismerősei, vagy akár Szilárd számára a swingerezők), az interjúalany párhuzamba állított páros szexuális vagy hármas párkapcsolati tapasztalataival (Emesénél és Szilárdnál), vagy a többi résztvevő perspektíváival (Szilárdnál, Márknál). Eltérő narrációs technikákkal mutatták be a hármas eseményt, a tömör összefoglalástól részletes kontextualizálásig; a hozzárendelt értékelések is széles skálán mozogtak, a lelkesedés hangjaitól az önpusztítás hasonlataiig.

Annak volt negatív élmény a hármas, aki nem találta meg benne az igényeinek legmegfelelőbb szexualitást, vagy ellentétesnek érzi azzal - ez pedig nagyban függ a rendelkezésre álló diszkurzív keretektől. Juli tapasztalatainak megfeleltethető társadalmilag elfogadott narratíva ugyanis nincs, nem tud azonosulni sem a homofób konzervativizmus, sem a neoliberális meleg-aktivista diskurzusokkal. Az ő hármas narratívája ezért sem történet, hanem önelemző magyarázat a kellemetlen szexuális élményeivel kapcsolatban, az identitáskereső jelen perspektivájából. Ugyan Márk szexuális igényei sem felelnek meg a meleg vagy a polgári-heteroszexuális életút mintáinak, de azok a hármasokban megvalósulnak, és a révbe érkezés, felelős felnőtté válás keretébe tudnak ágyazódni. Velük ellentétben Emese és Szilárd a meleg önmegvalósító diskurzusba, coming out narratívákba tudják illeszteni hármas tapasztalataikat. Szilárd számára a melegség sikertörténet, amelynek a hármas időszak volt az elindítója a függetlenedésben, önállóságban (anyagilag és szellemileg is), a szabadság és szeretet alternatív formáinak megélésében. Emese biszexuális identitása sem zárja ki egy hasonló narrativ minta követését, mert leszbikus vonzalmai felfedezésében fontos lépcsőfok volt a hármas.

Az interjúelemzések alapján megállapítható, hogy a biszexuális hármas tapasztalatát nem csak a férfiak és nők iránti vonzalmak határozzák meg; valamint, hogy ezen vonzalmakat sem csupán a női és férfi test biológiai különbségei befolyásolják. Egy szexuális hármas nem egyszerűen azért lesz valakinek pozitív élmény, mert biszexuális vágyai vannak, amelyek úgy teljesednek be, ha egyszerre lehet férfival és nővel. A hármassal kapcsolatos tapasztalataikat az interjúalanyaim nem kapcsolták össze direkt módon szexuális orientációjuk kérdésével, nem azonosították magukat a hármas szex alapján biszexuálisként. Sőt, akinek nem volt pozitív élmény (Julinak 
és Emesének), annak sem a mindkét nem jelenléte miatt, hiszen Juli a páros intimitásra törekszik, Emese pedig továbbra is érdeklődik férfiak iránt. Ő a testi jellemzőkön túlmutató szexuális mód változatos formáit és így saját androgünitását tapasztalta meg, míg Juli elbeszélése ahhoz a felismeréséhez kapcsolódik, hogy a mindkét nemre irányuló szexuális vágyban összekeveredtek a baráti és szerelmi érzések. Szilárd számára éppen ezek társadalmi előnyökkel, stabilitással és ideiglenességgel is összefonódó, nehezen szétszálazható hálózata tette örömtelivé a hármast, ahogy későbbi, akár egynemű kapcsolatait is. Márknak a nő az otthonosság, a férfiak a változatosság izgalmát jelentik - kettejük esetében, úgy tűnik, azért volt kellemes és visszatérő élmény a hármas, mert egyfajta teljességélményt adott. Azonban egyikük sem definiálja magát egyértelműen biszexuálisnak, mindketten meleg irányba hajló férfiak, tévedés lenne tehát a biszexuális identitást ezzel a teljesség-igénnyel magyarázni. Azaz még amikor dichotóm igényekről számolnak be az interjúalanyok, a komplementaritás élményét akkor sem pusztán a nemek testi különbözősége segíti elő, hanem az ismerős/idegen, megszokott/ új, átmeneti/stabil, szeretett/vágyott, baráti/szerelmi, elfogadott/tiltott, szabályozott/kikísérletezett társadalmi viszonyokba ágyazott kettősségei.

Tehát a nő és a férfi társadalmi jelentése messze túlmutat az egyes - szintén esetlegesen különböző vagy hasonló - testi tulajdonságokon, igazolva a queer megközelítést, hogy a szexuális orientáció nemekhez kötése redukálja a személyes tapasztalatokat és vágyakat, és egyben elkendőzi a nemek különbözőségének társadalmi vetületeit (ami tulajdonképpen a gender) (Young 1997, Butler 2005, 2006). Nemcsak szexuális orientációról és nemekről van szó; a partnerek nem pusztán egy-egy nem képviselői, hanem eltérő személyközi kapcsolatokat is megjelenítenek, és ezáltal az interjúalany személyiségét is különböző, változó relációs pozíciókba rendelik: Emesét nőként férfiba, Julit barátként szexpartnerbe, Márkot élettársból testbe (sőt testből eszközbe), Szilárdot szeretőből szeretettbe. A partnerek (egymást első látásra komplementeren kiegészítő) nemi különbözőségében fejeződik ki egy sor egyéb társadalmi jellemző, amelyek megélését van, aki „egyszerre” is igényli, de van, aki szívesebben különválasztja. A biszexuális hármas lehetőséget adott az interjúalanyoknak különböző szerepek és viszonyulások megtapasztalására, amelyekben saját nemi és szexuális határaikkal, határátlépéseikkel is szembesültek.

Mind a négy interjúalanyom megfogalmazta a hármas élményen keresztül, hogy milyen szexuális igényei vannak, és ezáltal milyen más szexualitásoktól határolja el magát. Ez a határhúzás azt is demonstrálja, hogy a monogámia tagadása és a biszexualitás bizonyos formáinak elfogadása sokszor együtt jár más formák normatív elítélésével (Ault 1996, Garber 1996). A homofób diskurzusokban két nő férfiakat bevonó szexuális együttléte elfogadható, két férfié nem; Szilárd és Márk szexuális gyakorlatai így társadalmilag megbélyegzettek; Szilárd az érzelmeket hangsúlyozva ad nekik értéket, ezért lehet, hogy Márkról is elítélően nyilatkozna; aki azonban a tisztes polgári keretek nevében megtehetné Szilárddal ugyanezt. Juli a szerelem nélküli és a többszereplős szexet nem érzi magáénak, Emese pedig a konszenzusos nyitott kapcsolatban való részvételt nem tudja elfogadni. Látható egyfelől, hogy a normativitás és a transzgresszív, normákat elutasító queer hozzáállás sokszor egyszerre van jelen ugyanabban a narratívában, ahogyan az interjúalanyok a hármasban való részvételüket a társadalmi normák tükrében értelmezik. Másrészt sokszor nem egyértelmű, mennyiben beszélnek saját preferenciáikról, és mennyiben implikálják más szexuális gyakorlatok, életformák elítélését, Juli például érvként említette az ismerőseinek szintén kellemetlen hármas élményét, de azonnal hozzátette, hogy másnak múködhet jól. 
Az interjúelemzés rámutat az interjúalany nemének jelentőségére, és így a férfi és női biszexualitás és hármas együttlét különbségeiben megjelenő hatalmi viszonyokra. A nők szexualitásában, azon belül is a biszexuális együttléteikben megjelenő férfikontroll (Fahs 2009) elemei megjelennek ezekben a történetekben, de az interjúalanyaimnak volt mozgásterük ennek alakításában. Juli akkori befolyásolhatóságának tulajdonítja részvételét a baráti hármasban, viszont nem ő, hanem a barátnője volt ott jelen heteroszexuális párkapcsolatban (akinek szerepéről, hozzáállásáról semmit nem tudunk). Emese történetében a fiatalabb lány kezdeményezte egy férfi irányító jelenlétét, amibe ő, felismerve a kompromisszumot, beleegyezett. Mindkét női interjúalanyom egyszer ment bele egy számára labilis helyzetbe, és úgy vélik, ma már nem tennék meg. Hiába vonzódtak nőkhöz és férfiakhoz is, az ő szexuális, szerelemi és baráti igényeiknek nem felelt meg a hármasnak az a legsztereotipabb, legláthatóbb elképzelése, amelyben (sokszor egy heteroszexuális párkapcsolat alkalmi kiegészítéseként) a két nő közti viszony a férfi részvételével (irányításával és örömére) folyik le. Férfi interjúalanyaimnál azonban múködött a két férfi-egy nő összetételű hármas - éppen azért, mert nagyobb kontrolljuk volt az együttlét fölött. Márk a párjával közösen tervezve, aktívan keresett harmadik felet, saját biszexuális vágyainak megélésére. Szilárd pedig szinte kerítő szerepben szervezte meg a hármasaikat, a két fiatalabb résztvevő aktusát mint saját „múvét” nagyrészt kívülről szemlélve. Az ő esetükben még standard párkapcsolatról sem beszélhetünk, inkább a barátság-szerelem skáláján mozgó, nehezen kategorizálható relációk összetett hálózatáról.

Interjúalanyaim tehát nem csupán nőre és férfira vágynak, amikor nőre és férfira vágynak. Ha a férfi és nő, homo- és heteroszexualitás, szex és érzelem, szerelem és barátság közötti határvonalak társadalmi konstrukciójának keretében értelmezzük a hármasozást, a nemeknek a szexuális vágyakban és élményekben betöltött szerepe összetettebben jelenik meg, és a rájuk rakódott társadalmi jelentések láthatóbbakká válnak, a nemi és szexuális kategóriák közti határvonalak pedig feloldódnak. 


\section{HIVATKOZÁSOK}

Albert F. (2014) A férfiak és nők közti különbségek és hasonlóságok a barátságban. Replika 85-86, 165-176.

Ault, A. (1996) The dilemma of identity. Bi women's negotiations. In Seidman S. (szerk.) Queer Theory / Sociology. Cambridge: Blackwell, 311-330.

Borgos A. (2010) Nemek között - a bifóbia elmélete és gyakorlata. In Gantner B. E. - Schweitzer G. - Varga P. (szerk.) Kép-keret. Az identitás konstrukciói. Budapest: Nyitott Könyvmúhely, 101-114.

Borgos A. (2014) Eltitkolt évek - mozaikok a magyar leszbikus herstoryból. Replika 85-86, 123-146.

Butler, J. (2006 [1990]) Problémás nem: feminizmus és az identitás felforgatása. [Berán E. - Vándor J. ford.] Budapest: Balassi.

Butler, J. (2005 [1993]) Jelentős testek: a szexus diszkurzív korlátairól. [Barát E. - Sándor B. ford.] Budapest: Új Mandátum.

Denzin, N. K. - Lincoln, Y. S. (szerk.) (2003) Collecting and Interpreting Qualitative Materials. London: Sage.

Diamond, L. M. (2006) Careful What You Ask For: Reconsidering Feminist Epistemology and Autobiographical Narrative in Research on Sexual Identity Development. Signs 31, 471-491.

Dollimore, J. (1996) Bisexuality, heterosexuality, and wishful theory. Textual Practice 10, 523-539.

Easton, D. - Hardy, J.W. (2009) The Ethical Slut. Berkeley: Celestial Arts.

Eisner, S. (2013) Bi. Notes for a Bisexual Revolution. Berkeley: Seal Press.

Fahs, B. (2009) Compulsory Bisexuality? The Challenges of Modern Sexual Fluidity. Journal of Bisexuality 9:3, $431-449$.

Foucault, M. (1999) A szexualitás története I-III. [Ford. Ádám P.] Budapest: Atlantisz.

Garber, M. (1996) Vice Versa. Bisexuality and the Eroticism of Everyday Life. London: Penguin Books.

Gubrium, J. F. - Holstein, J. A. (szerk.) (2003) Inside Interviewing. New Lenses, New Concerns. Thousand Oaks: Sage.

Hemmings, C. (2002) Bisexual Spaces. London/New York: Routledge.

Jagose, A. E. (2003) Bevezetés a queer-elméletbe [Sándor B. ford.] Budapest: Új Mandátum.

Kalocsai Cs. - Takács J. (szerk.) (1998) Leszbikus és meleg identitáspolitikák. Replika 33-34, 193-257.

Kimmel, M. S. (szerk.) (2007) The Sexual Self. The Construction of Sexual Scripts. Nashville: Vanderbilt University Press.

Kinsey, A. C. - Pomeroy, W. B. - Martin, C. E. (1999 [1948]) Extracts from 'Sexual Behavior in the Human Male'. In Storr, M. (szerk.) Bisexuality - A Critical Reader. New York/London: Routledge. 31-37.

Kinsey, A. C. -Pomeroy W. B. -Martin C. E. (1965 [1953]) Sexual Behavior in the Human Female. Philadelphia: Saunders.

Kovács É. - Vajda J. (2002) Mutatkozás. Zsidó identitás történetek. Budapest: Múlt és Jövő.

Kovács É. (2007) Narratív biográfiai elemzés. In uő. (szerk.) Közösségtanulmány. Módszertani jegyzet. Budapest-Pécs: Néprajzi Múzeum, PTE-BTK Kommunikáció- és Médiatudományi Tanszék, 373-396.

Laumann, E. O. - Gagnon, J. H. (1995) A sociological perspective on sexual action. In Parker, R. G. - Gagnon, J. H. (szerk.) Conceiving Sexuality. New York/London: Routledge, 183-213.

Melegh A. (2006) On the East/West Slope. Globalization, Nationalism, Racism and Discourses on Central and Eastern Europe. New York - Budapest: CEU Press.

Németh B. (2008) Leszbikus narratívák. In Bakó B. - Tóth E. Zs. (szerk.) Határtalan nők. Kizártak és befogadottak a női társadalomban. Budapest: Nyitott Könyvmühely, 259-284.

Plummer, K. (1995) Telling Sexual Stories. London/New York: Routledge.

Radnóti S. (2007) Az egy és a sok. In Rácz I. P. (szerk.) Testre szabott élet. Írások Nádas Péter Saját halál és Párhuzamos történetek címü müveiröl. Budapest: Kijárat, 219-262.

Riessman, C. K. (1993) Narrative Analysis. London: Sage.

Scott, J. W. (1992) Experience. In Butler, J. - Scott, J. W. (szerk.) Feminists theorize the Political. New York and London: Routledge, 22-40.

Sedgwick, E. K. (1985) Between Men - English Literature and Male Homosocial Desire. New York: Columbia University Press.

Seidman, S. (1996) Introduction. In uő. (szerk.) Queer Theory / Sociology. Cambridge: Blackwell, 1-30.

Tengelyi L. (1998) Élettörténet és Sorsesemény. Budapest: Atlantisz. 
Tiefer, L. (1995) Sex is Not a Natural Act and Other Essays. San Francisco: Westview Press.

Turai K. R. (2010) "Hard to tell in a word" - bisexual narratives in contemporary Hungary. MA szakdolgozat. Kéziratban. Budapest: Central European University.

Turai K. R. (2011) A biszexualitás, a homofóbia és a bifóbia összefüggései. In Takács J. (szerk.) Homofóbia Magyarországon. Budapest: L'Harmattan, 55-68.

Weston, K. (1998) Long slow burn: sexuality and social science. New York: Routledge.

Wilkinson, E. (2010) What's queer about non-monogamy now? In Barker, M. - Langdridge, D. (szerk.) Understanding Non-Monogamies. New York: Routledge, 243-254. 